\title{
Geologic framework of the 2005 Keathley Canyon gas hydrate research well, northern Gulf of Mexico
}

\author{
D.R. Hutchinson ${ }^{\mathrm{a}, *}$, P.E. Hart ${ }^{\mathrm{b}}$, T.S. Collett ${ }^{\mathrm{c}}$, K.M. Edwards ${ }^{\mathrm{a}}$, D.C. Twichell ${ }^{\mathrm{a}}$, F. Snyder ${ }^{\mathrm{d}}$ \\ ${ }^{a}$ U.S. Geological Survey, Woods Hole, MA 02543, USA \\ ${ }^{\mathrm{b}}$ U.S. Geological Survey, Menlo Park, CA 94025, USA \\ ${ }^{c}$ U.S. Geological Survey, Denver, CO 80225, USA \\ ${ }^{\mathrm{d}}$ WesternGeco, Schlumberger Data and Consulting Services, Houston, TX 77042, USA
}

\section{A R T I C L E I N F O}

\section{Article history:}

Received 19 March 2007

Received in revised form 13 June 2007

Accepted 4 January 2008

\section{Keywords:}

Gulf of Mexico

Gas hydrate

Methane hydrate

Geologic framework

Joint industry projects

JIP

\begin{abstract}
A B S T R A C T
The Keathley Canyon sites drilled in 2005 by the Chevron Joint Industry Project are located along the southeastern edge of an intraslope minibasin (Casey basin) in the northern Gulf of Mexico at $1335 \mathrm{~m}$ water depth. Around the drill sites, a grid of 2D high-resolution multichannel seismic data designed to image depths down to at least $1000 \mathrm{~m}$ sub-bottom reveals 7 unconformities and disconformities that, with the seafloor, bound 7 identifiable seismic stratigraphic units. A major disconformity in the middle of the units stands out for its angular baselapping geometry. From these data, three episodes of sedimentary deposition and deformation are inferred. The oldest episode consists of fine-grained muds deposited during a period of relative stability in the basin (units e, $\mathrm{f}$, and $\mathrm{g}$ ). Both the BSR and inferred gas hydrate occur within these older units. The gas hydrate occurs in near-vertical fractures. A second episode (units $\mathrm{c}$ and $\mathrm{d}$ ) involved large vertical displacements associated with infilling and ponding of sediment. This second interval corresponds to deposition of intercalated fine and coarse-grained material that was recovered in the drill hole that penetrated the thin edges of the regionally much thicker units. The final episode of deposition (units a and b) occurred during more subdued vertical motions. Hemipelagic drape (unit a) characterizes the modern seafloor. The present-day Casey basin is mostly filled. Its sill is part of a subsiding graben structure that is only $10-20 \mathrm{~m}$ shallower than the deepest point in the basin, indicating that gravity-driven transport would mostly bypass the basin. Contemporary faulting along the basin margins has selectively reactivated an older group of faults. The intercalated sand and mud deposits of units $\mathrm{c}$ and $\mathrm{d}$ are tentatively correlated with Late Pleistocene deposition derived from the western shelf-edge delta/depocenter of the Mississippi River, which was probably most active from $320 \mathrm{ka}$ to $70 \mathrm{ka}$ [Winker, C.D., Booth, J., 2000. Sedimentary dynamics of the salt-dominated continental slope, Gulf of Mexico: integration of observations from the seafloor, near-surface, and deep subsurface. In: Proceedings of the GCSSEPM Foundation 20th Annual Research Conference, Deep-water Reservoirs of the World, pp. 1059-1086]. The presence of sand within the gas hydrate stability zone (in units c and d) is not sufficient to concentrate gas hydrate even though dispersed gas hydrate occurs deeper in the fractured mud/clay-rich sections of units e and f.
\end{abstract}

Published by Elsevier Ltd.

\section{Introduction}

While general characteristics of the hydrate stability zone (HSZ) can be estimated with pressure, temperature, and gas solubility parameters, the geologic setting is also critical for understanding factors that control the distribution and concentration of marine gas hydrates (Clennell et al., 1999; Nimblett and Ruppel, 2003; Trehu et al., 2004; Xu and Ruppel, 1999). Lithology and structure,

\footnotetext{
* Corresponding author. Tel +1 (508) 4572263.

E-mail address: dhutchinson@usgs.gov (D.R. Hutchinson).
}

together with the sometimes complicated history of deposition and deformation, are known to affect the distribution and concentration of hydrate (Expedition 311 Scientists, 2006; Reidel et al., 2006; Trehu et al., 2004). Although the northern Gulf of Mexico (hereafter referred to simply as the Gulf) is a passive continental margin, the continental slope is remarkably complex and heterogeneous because of widespread salt tectonism, differential Pleistocene sediment loading, and consequent large variations in sediment patterns and structural style (Bryant et al., 1990; Diegel et al., 1995; Peel et al., 1995). Hence, understanding the geologic setting around the Joint Industry Project (JIP) drill holes sets the stage for understanding the factors affecting distribution of gas hydrate within the sedimentary section. 
Most of the documented gas hydrate in the northern Gulf comes from seafloor mounds or piston cores less than several meters long (Brooks et al., 1984; MacDonald et al., 1994; Roberts and Carney, 1997; Sassen et al., 2001). Prior to JIP drilling, the deepest subsurface hydrate sample came from DSDP site 618 in the Orca Basin, in which gas hydrate was identified at $20-40 \mathrm{~m}$ below the seafloor (mbsf) (Pflaum et al., 1986). Until recently, most knowledge about gas hydrates in the northern Gulf was from surface and shallow subsurface samples clustered in the upper slope because of depth limitations of the submersibles used to study them (MacDonald et al., 1994; Roberts and Carney, 1997; Sassen et al., 2004). The general paucity of bottom simulating reflections (BSRs) (Cooper and Hart, 2003) meant that there were few convincing indicators for justifying the expense of a drilling program dedicated to validating the presence of deeper gas hydrates. The recent JIP drill sites therefore represent one of the first attempts to identify gas hydrate in sub-seafloor environments in the Gulf of Mexico.

The basis for drilling the two JIP drill holes at the Keathley Canyon site (Fig. 1) in the northern Gulf of Mexico was detection of a low-amplitude BSR (Dai et al., 2004; Snyder et al., 2004; Xu et al., 2004). While the BSR technically only indicates the presence of free gas presumably trapped beneath the HSZ (Andreassen et al., 1997; Bangs et al., 1993), the common assumption has been that trapped free gas is a harbinger of enough gas to support hydrate formation within the HSZ (Dillon and Paull, 1983; Kvenvolden, 1993). This assumption has in general held true, although exceptions, in which the BSR occurs without any measurable hydrate and hydrate occurs without a BSR, are known (Holbrook, 2001; Johnson and Smith, 2006). The characteristics of the BSR at the Keathley Canyon site, including its areal extent, depth, associated amplitude anomalies, and consistency with thermal-gradient measurements, are described elsewhere (Hutchinson et al., 2008). In this paper, we describe the seismic stratigraphy near the drill holes and relate the drilling results to this stratigraphic framework.

\section{Geologic setting of the northern Gulf of Mexico}

The Gulf of Mexico is a relatively small ocean basin in which a short episode of seafloor spreading occurred in middle Mesozoic time (Bird et al., 2005; Pindell and Dewey, 1982; Salvador, 1987). Middle Jurassic Louann salt that was deposited during rifting or early postrifting time became mobilized in middle Cenozoic time (Diegel et al., 1995; Salvador, 1991) and has controlled formation of much of the gross surface morphology and stratigraphy of minibasins and intervening structural highs in the northern Gulf (Diegel et al., 1995; Ewing, 1991; Peel et al., 1995). Remobilization occurred in Plio-Pleistocene time owing to differential loading of the shelf as sediment depocenters migrated back and forth across the continental shelf in response to changing sea level (Bryant et al., 1990). During sea level low stands, sediments bypassed the continental shelf into shelf-edge deltas that channeled terrigenous deposits into slope basins and fans (Suter and Berryhill, 1985; Lee et al., 1996). Depositional loading caused the more viscous salt to flow, creating basins (where the salt had withdrawn) and structural highs surrounding the basins (where the displaced buoyant salt had risen upwards), as described by Diegel et al. (1995) and Peel et al. (1995). Mass wasting during sea level low stands further augmented delivery of sediment, especially sands, to deeper-water locations (Booth, 1979; Coleman et al., 1983). During sea level high stands, such as the current Holocene configuration, deltas retreated back from the shelf-edge, trapping the sediment load in a more landward position. As in previous sea level high stands, much of the slope and rise are currently sediment starved (Coleman et al., 1991).

The northern Gulf of Mexico is one of the most extensively drilled continental margins in the world because of its world-class petroleum system (Nehring, 1991). Both oil slicks and gas bubbles

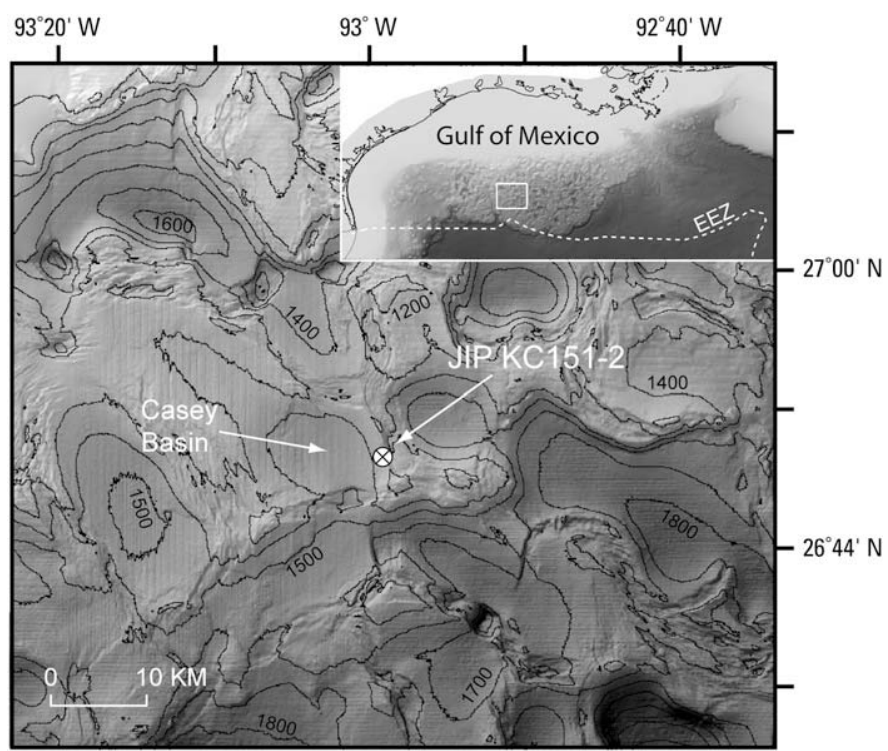

Fig. 1. Location map showing the northern Gulf of Mexico (inset) with the minibasin distribution around the KC 151-2 drill sites. Bathymetry here and in Fig. 2 is from the NOAA Gulf of Mexico coastal relief model (Divins and Metzger, 2004).

at the sea surface identified by a variety of techniques (MacDonald et al., 1993, 1996) are evidence that the petroleum system is also leaky (Roberts and Aharon, 1994; Whelan et al., 2005). Gas hydrate occurrence has been linked to seep locations (Roberts and Aharon, 1994) where faults along the edges of buried salt bodies are interpreted to be the conduits bringing deeper hydrocarbon fluids to the seafloor (Roberts, 1995; Roberts et al., 1998). Both thermogenic and biogenic gas have been associated with gas hydrate samples from the northern Gulf (Anderson et al., 1983; Sassen and MacDonald, 1997; Sassen et al., 1998).

In the Keathley Canyon region, the KC 151-2 JIP drill site is on the southeastern edge of an intraslope basin (Casey basin) that is slightly elongated in a northwest-southeast direction and is $\sim 12 \mathrm{~km}$ wide (Fig. 1). The drill hole, in $1335 \mathrm{~m}$ water depth, lies $\sim 260 \mathrm{~m}$ from the East Casey fault zone that defines the eastern edge of the intraslope basin and western edge of the adjacent saltcored structural high (Fig. 2). The Casey basin is currently open to the south; the southern sill at $1460 \mathrm{~m}$ is $\sim 10-20 \mathrm{~m}$ shallower than the deepest point of the basin (1470-1480 m), indicating that the basin is currently almost filled and cannot trap additional large thicknesses of sediments. This geometry is typical of a bypass system, in which most shelf-derived sediments pass through the basin and are deposited further downslope (Prather et al., 1998; Winker and Booth, 2000).

Ages of sediments within the Casey basin are not constrained. Core recovery was incomplete in the JIP drill hole (e.g., core samples lacking from 45 to 100 mbsf, Claypool, 2006), and biostragraphic studies have not been undertaken. The two nearest wells are outside the Casey basin at distances of $\sim 17 \mathrm{~km}$ (KC 199) and $\sim 27 \mathrm{~km}$ (GB 941) (W. Shedd, 2007, personal communication). Neither of these wells provided age constraints. The KC 199 well, located in a basin east of the Casey basin, did not retrieve paleontologic information in the shallowest $890 \mathrm{~m}$ of the drill hole, and the GB 941 well, located in a structural high to the northeast, is separated from the Casey basin by at least one large fault across which seismic stratigraphic correlations are unclear. Plio-Pleistocene deposits in the centers of other mid-slope basins reach more than $6 \mathrm{~km}$ in thickness (Peel et al., 1995) with Quaternary deposits often exceeding $3 \mathrm{~km}$ (Coleman et al., 1991). These large thicknesses suggest the shallow stratigraphic units imaged in the Casey basin are likely to be Pleistocene and Holocene in age. 


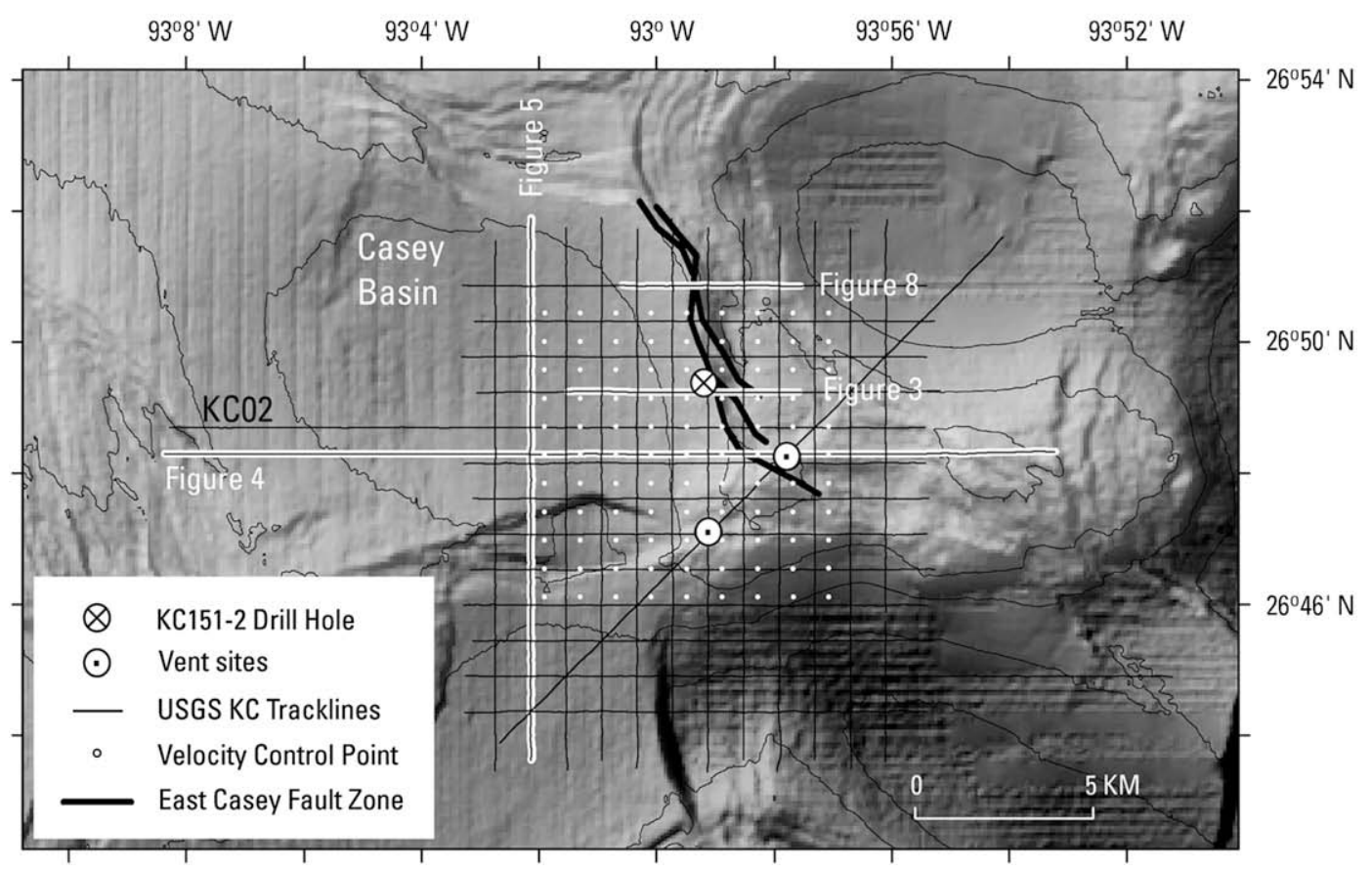

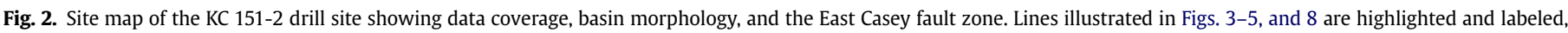
respectively. Vent sites are from Hutchinson et al. (2008). Vent Beta is the northeastern most of the two mapped vents.

The thickness of the HSZ around the KC 151-2 drill site is estimated (from BSR depths) to increase from $250 \mathrm{~m}$ at the basin edges to greater than $400 \mathrm{~m}$ towards the center of the basin (Hutchinson et al., 2008). Detailed descriptions and analysis of the BSR are given in Hutchinson et al. (2008).

The structural high defined by uplift along the East Casey fault zone is a region of structural and stratigraphic complexity. Salt rises to within $\sim 1 \mathrm{~km}$ of the seafloor beneath the structural high (Hutchinson et al., 2008) and is probably many kilometers deep beneath the adjacent minibasin (Diegel et al., 1995; Peel et al., 1995). The BSR extends across the faulted structural high from the drill site to at least as far as vent Beta (Fig. 2) (Hutchinson et al., 2008; Snyder et al., 2004). The lack of offset in the BSR across the East Casey fault suggests that the fault is not currently a conduit for warm fluids from depth (Hutchinson et al., 2008). However, other indicators of gas in the structural high suggest that fluid flow is or has been active in the recent past: bright spots, blanking, chimney structures, and possible seafloor vents (Hutchinson et al., 2008). Despite the structural and stratigraphic complexity, the observation of a BSR and other acoustic evidence of potential gas in the subsurface suggested that the Keathley Canyon intraslope basin site was an appropriate target for drilling subsurface gas hydrate.

\section{Data}

The seismic data used in this analysis consist of $\sim 380 \mathrm{~km}$ of high-resolution multichannel seismic reflection data collected by USGS in 2003 (Hart et al., 2005; Hutchinson and Hart, 2004). Data quality is excellent, although the small source size ( $13 \mathrm{in}^{3} \mathrm{GI}$ airgun) limits penetration generally to the uppermost $1-1.5 \mathrm{~s}$ two-way travel time (twtt) or about the uppermost $1000 \mathrm{~m}$ of section. These depths are adequate for imaging the HSZ in these water depths, but are not appropriate for imaging the deeper stratigraphy and structure controlling the regional geology. Line spacing was $1 \mathrm{~km}$ in a grid-based layout (Fig. 2).

The short streamer length $(200 \mathrm{~m})$ in water depths greater than $1 \mathrm{~km}$ precludes obtaining accurate velocities from analysis of normal moveout. Therefore, to convert seismic travel times to depth, a grid of velocities from a 3D multichannel seismic data set from this area acquired with an 8-km-long streamer were incorporated into the analysis (Snyder et al., 2004; Xu et al., 2004). These velocity control points (Fig. 2) do not cover the entire survey area; therefore depths are more accurate only in the region of velocity control points. Standard Dix analysis was used in converting stacking velocities to depths (Dix, 1955). Line KC03, closest to the drill hole, was depth converted (Fig. 3). Interpretation and mapping of seismic horizons were completed on unmigrated data, for which errors in line ties are minimized. Migrated data were used to interpret fault locations and are used to illustrate representative horizons and units (Figs. 4 and 5).

Two drill holes located $\sim 10 \mathrm{~m}$ apart were completed in the Keathley Canyon drilling program: KC 151-2 and the slightly updip KC 151-3. Only logging while drilling (LWD) was conducted at hole KC 151-2, whereas core samples and wire-line logging data were collected from KC151-3. Interpretations of the JIP drilling data used in this paper are based on the gamma-ray and ring resistivity logs (from the GeoVision tool) collected in the LWD program in KC 151-2 as described in Claypool (2006) and Cook and Goldberg (2006). Synthetic seismograms constructed from the logging data are in good agreement with seismic reflection data at the drill hole (Lee and Collett, 2008).

\section{Seismic stratigraphy}

In an analysis linking seismic stratigraphy with well data for intraslope basins in the upper and middle slope of the northern Gulf, Prather et al. (1998) used four stratal characteristics to identify depositional environments (Table 1): convergent baselapping, in which the units progressively fill and lap onto a basal disconformity; convergent thinning, in which generally concordant reflections thin laterally updip; draping, in which subparallel reflections drape over paleotopography; and chaotic, in which few laterally continuous or coherent reflections occur. The boundaries between these units are characterized either as conformities, which 

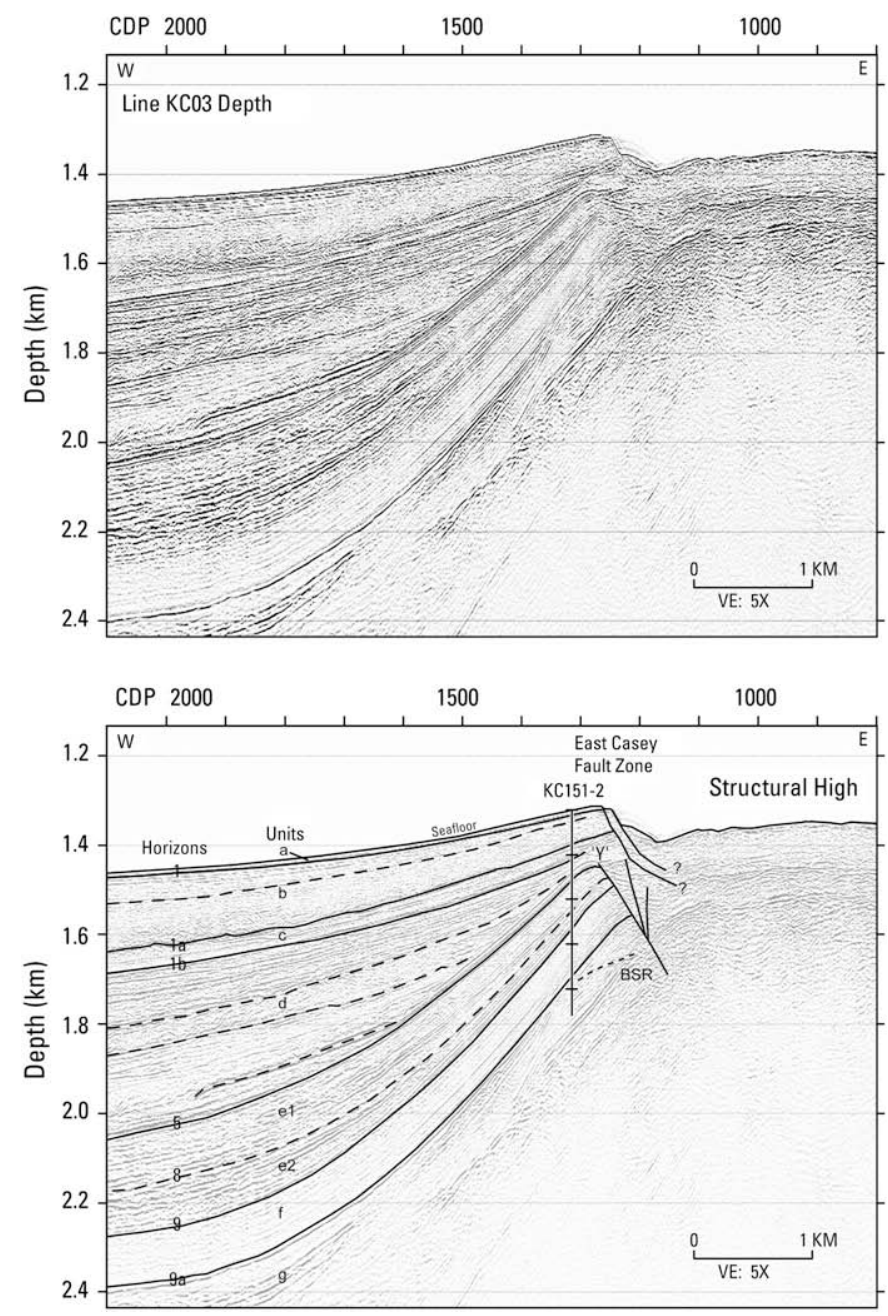

Fig. 3. Depth section of east-west line KC03. Upper panel is uninterpreted. Lower panel shows seismic stratigraphic interpretation including location of drill hole KC 151-2. Lettered units (a-g) are separated by numbered horizons (solid lines). Subunits $\mathrm{e} 1$ and $\mathrm{e} 2$ are the only subunits named in the interpretation and are separated by a dashed line representing horizon 8. Other subunits are not named but are indicated by dashed-line boundaries. Location is shown in Fig. 2, and seismic stratigraphic units are summarized in Table 2.

follow concordant strata although there may be local truncation, or disconformities, which contain evidence for erosion, nondeposition, or a significant hiatus even if the horizon is concordant in places (Prather et al., 1998). Prather et al. (1998) further distinguish high-impedance and low-impedance subcategories within their broader classification. These are interpreted to indicate relatively sand-prone (high reflectivity) and mud- or clay-prone (low reflectivity) turbidite/fan facies. Chaotic facies may include mass transport complexes consisting of mud-rich sections of slumps, slides, and debris flow deposits (Beauboeuf and Friedmann, 2000). Our analysis uses these categories, boundaries, and criteria to distinguish 7 units in the upper and lower portions of the seismic data in the Casey basin (Table 2, Figs. 3-5).

Near the JIP drill holes, the most prominent event in the shallow seismic section is a major disconformity (horizon 5 in Figs. 3-6, Table 2). This event is clear in all seismic sections and divides the stratigraphy into upper and lower packages. At the site of the drill hole, four units of distinct and different seismic character are identified in the upper package (units a, b, c, and $d$ bounded by the seafloor and horizons 1, 1a, 1b and 5). Three units, including one unit consisting of two parts, are identified in the lower package beneath the unconformity (units e-e1 and e2, f, and g, bounded by horizons 5, 9, and 9a, horizon 8 separates e1 and e2).

\subsection{Upper package}

In the upper package, units $\mathrm{b}$ and $\mathrm{d}$ have primarily chaotic seismic-stratigraphic character containing transparent zones. Discontinuous, arcuate, and sometimes wavy reflections occur, as do occasional, semi-continuous subparallel internal reflections of moderate to high amplitude. The seismic character of these units is highly variable. The upper thirds of both of these units show a transition to more convergent thinning style in the middle of the basin, although at the drill hole this convergent thinning material is either absent (top of unit b) or extremely thin (top of unit d). Unit $\mathrm{d}$ also shows classic baselap on horizon 5 in many of the seismic profiles (Figs. 4 and 5), indicating that this unit filled either a subsided or subsiding basin. Unit b has a hummocky basal surface (horizon 1a) suggesting that deposition was preceded by intervals of downcutting. The overall transparent, chaotic acoustic style of both units $b$ and $d$ suggests that they are dominated by discrete packages of mass wasting, channelized sand deposits, and submarine fan complexes, probably containing sand-prone intervals (Prather et al., 1998). An abundant sediment source bringing material to fill this accommodation space is consistent with interpretations of sea level low stands and shelf-edge deltas (Coleman et al., 1983; Suter and Berryhill, 1985; Winker and Booth, 2000).

Units a and c of the upper sequence, which are above units b and $\mathrm{d}$, respectively, are much thinner units that have well-imaged, subparallel, concordant layering. Unit a, which forms at the seafloor, has draping style, with little or no thickening into the middle of the basin $(<20 \mathrm{~m}$ thick). Although unit $\mathrm{c}$ is generally thin ( $\sim 40 \mathrm{~m}$ ) compared to units $\mathrm{b}$ and $\mathrm{d}$, it has a slight convergent thinning character towards the east. Both units have continuous to semi-continuous reflections of mixed high and low impedance. This concordant reflection style is characteristic of hemipelagic, fine-grained deposition at times of higher sea level and reduced sediment supply (Beauboeuf and Friedmann, 2000; Winker and Booth, 2000).

The units and horizons above disconformity 5 are abruptly terminated at the eastern edge of the basin by an eastward dipping fault zone (East Casey fault zone) with a scarp or series of scarps showing seafloor offsets up to $0.070 \mathrm{~s}$ twtt (or about $50 \mathrm{~m}$ ) (Fig. 6). In the vicinity of the JIP drilling, units $a, b$, and possibly also c therefore may have connectivity with sea water along this scarp. Further south, the scarp is less pronounced and these units remain buried. These scarp and reflector offsets indicate that the East Casey fault zone has been active recently, and neither erosion nor modern deposition has smoothed away the steep relief.

The East Casey fault zone marks the edge of the adjacent saltcored structural high (Hutchinson et al., 2008). As interpreted from other intraslope basins (Diegel et al., 1995), this salt has presumably flowed out of the middle of the basin creating the space for lensshaped deposition in the center of the basin and pushing up the edges of the basin into the structural highs. Salt flow was presumably most active during the formation of units $b$ and $d$, which show the greatest thickening into the basin. Few horizons from within the basin can be traced with any certainty across the complicated, diffractive acoustic character of the structural high.

\subsection{Lower package}

Beneath disconformity 5 , the seismic stratigraphy of the lower package is primarily convergent thinning. Unit e has a mixed chaotic and concordant reflection character, in which discontinuous reflections are interspersed with semi-continuous and transparent 

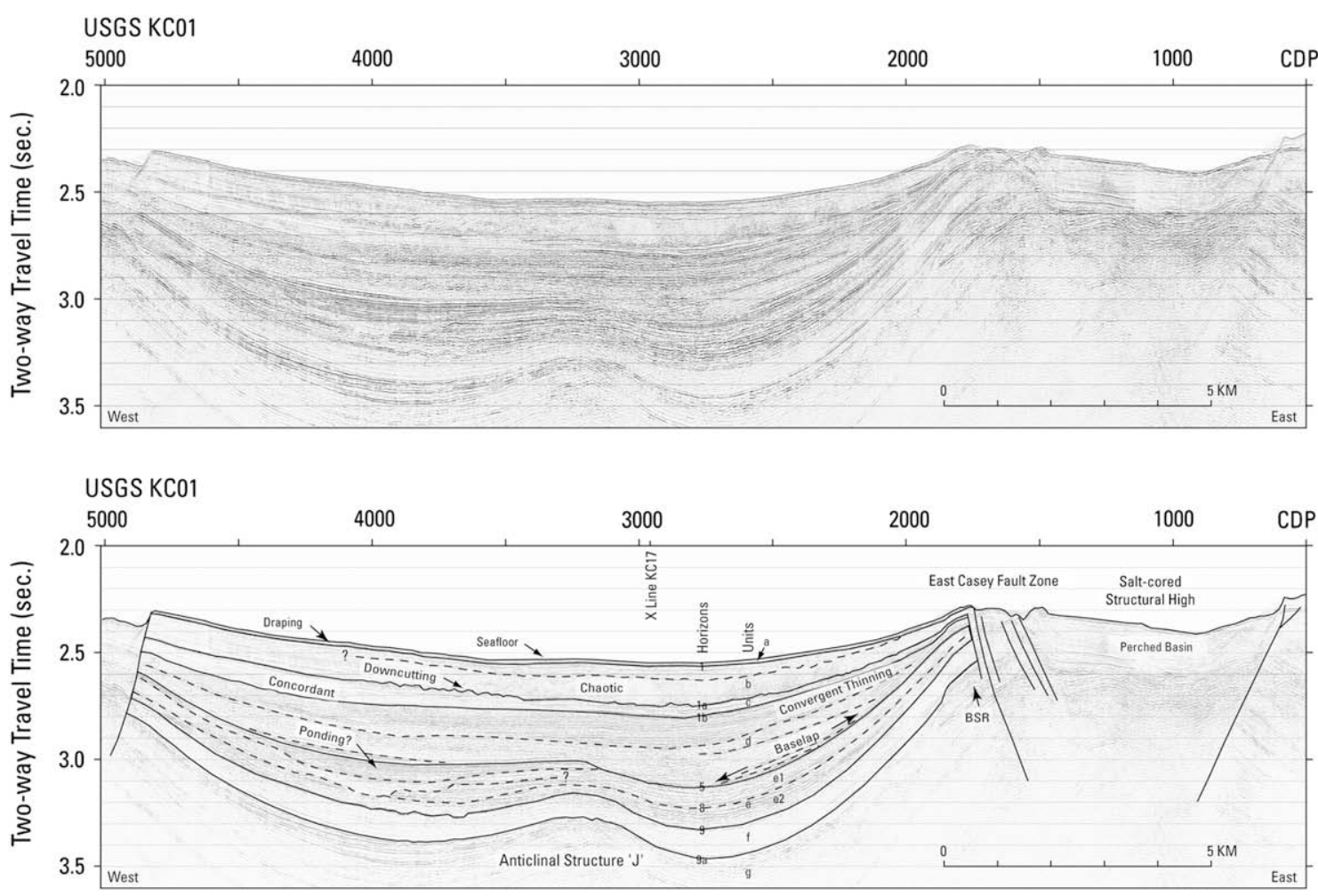

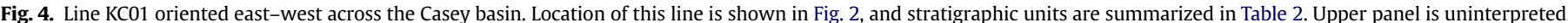

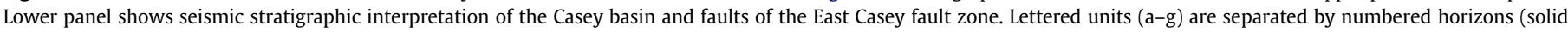

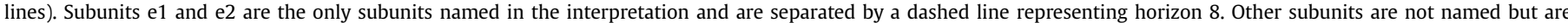

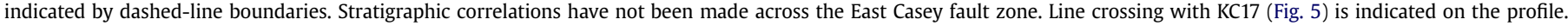

reflection bands. The basis for distinguishing subunits e 1 from e 2 is reflection strength: $\mathrm{e} 1$ has fewer high-impedance reflections than e2 and is overall of a lower reflectivity character. At the location of the drill holes, e1 is mostly low-strength reflections possibly indicative of mass-flow deposits; e2 has alternating stronger and weaker reflections, suggesting interleaved high-impedance and low-impedance units, possibly indicative of channelized deposits.

Unit $\mathrm{f}$, the deepest unit for which both the top and bottom of the unit is identified, is characterized by very low-impedance continuous to semi-continuous reflections that have slight convergent
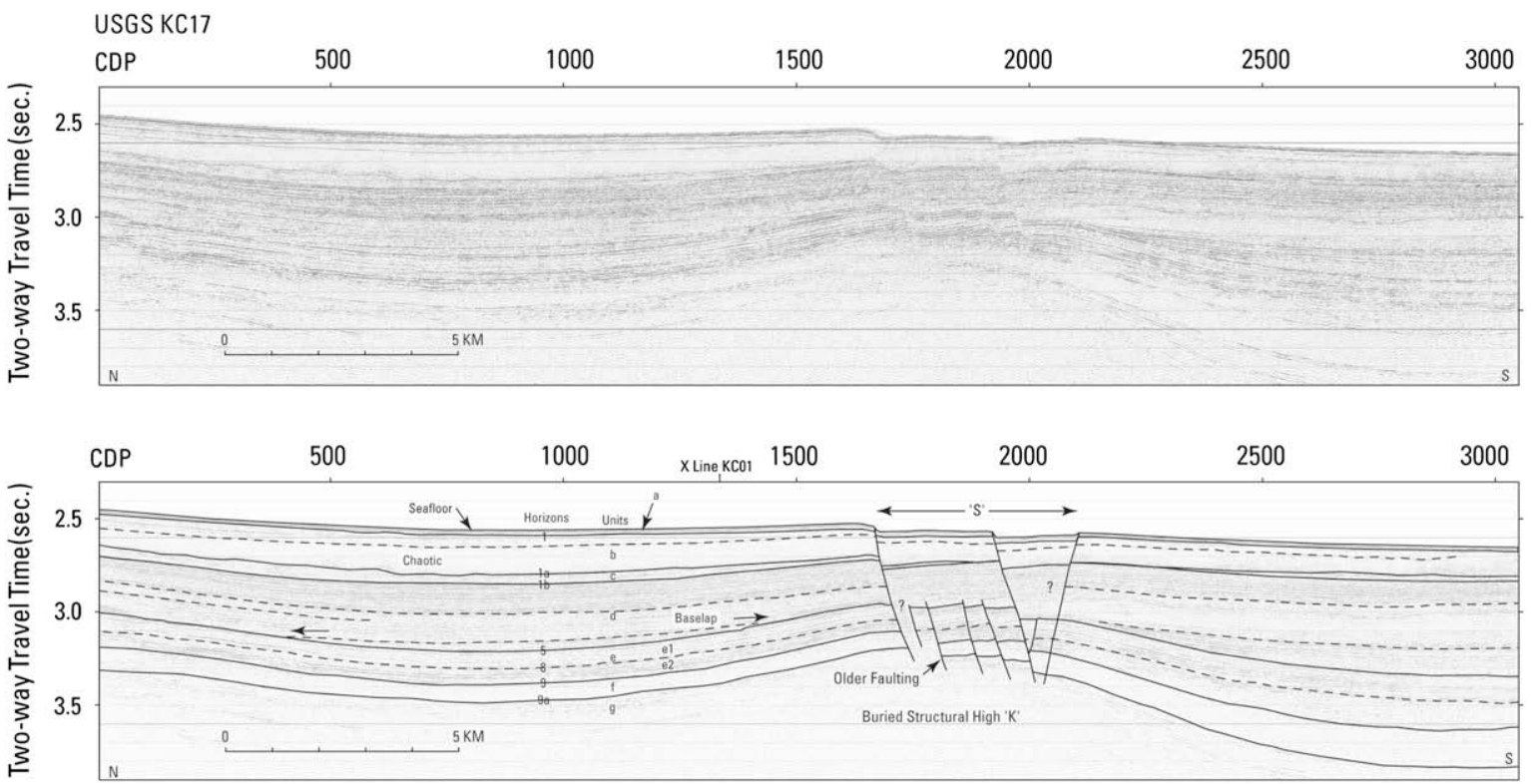

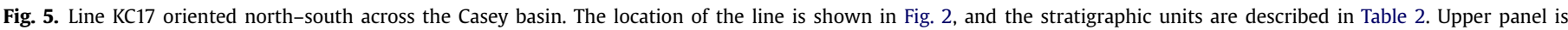

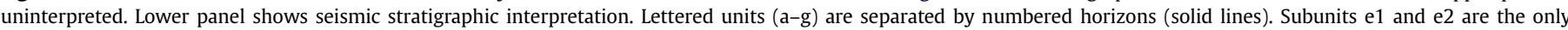

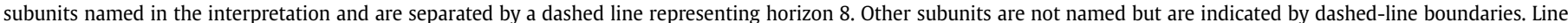
crossing with KC01 (Fig. 4) is indicated on the profile. 
Table 1

Summary of stratal classification, simplified from Prather et al. (1998)

\begin{tabular}{cl}
\hline Character & Description \\
\hline $\begin{array}{c}\text { Convergent } \\
\text { baselapping }\end{array}$ & $\begin{array}{l}\text { Stratal surfaces terminate against an underlying reflection; } \\
\text { usually occurs on the flanks of minibasins and is related to infilling } \\
\text { of the basin; generally indicates a surface along which there was } \\
\text { non-deposition and the presence of a hiatus }\end{array}$ \\
$\begin{array}{c}\text { Convergent } \\
\text { thinning }\end{array}$ & $\begin{array}{l}\text { Stratal surfaces are generally concordant, but thin without } \\
\text { baselap; reflection character can be semi-continuous to } \\
\text { continuous; high reflectivity zones suggest sand deposition; tend } \\
\text { to occur in the shallower parts of basins }\end{array}$ \\
Draping & $\begin{array}{l}\text { Highly continuous reflections that drape over paleotopography } \\
\text { and may thin towards the flanks of basins; generally thin units of } \\
\text { finer-grained sediment (mudstone, claystone); high-imedance } \\
\text { reflections may indicate some sand } \\
\text { Wavy, incoherent, discontinuous reflections of variable } \\
\text { reflectivity; baselap is common; sometimes possible to } \\
\text { distinguish rotated slump blocks; may be some downcutting into } \\
\text { older horizons; units may taper or be wedge-shaped }\end{array}$ \\
&
\end{tabular}

thinning. Although unit $\mathrm{f}$ is $\sim 120 \mathrm{~m}$ thick in the middle of the basin (Fig. 6), at the site of the drilling it is $\sim 80-90 \mathrm{~m}$ thick vertically, but only $\sim 65 \mathrm{~m}$ thick perpendicular to reflections. The low-amplitude of the reflections makes this unit appear transparent, although the weak fabric of concordant reflections is distinctly different from the transparent character of the chaotic zones in units b and $\mathrm{d}$. The lowimpedance character with concordant geometry suggests that unit $\mathrm{f}$ contains fine-grained muds or clays associated with hemipelagic deposition or fine-grained turbidites.

The deepest unit identified, unit $\mathrm{g}$, has a strong continuous reflection marking its upper conformable surface, but internally, reflections are discontinuous. Reflection segments range from weak to strong, and numerous hummocky events occur near its top in association with discontinuous chaotic and transparent zones. The bottom of unit $\mathrm{g}$ was not identified, as it lies below the lower limit of penetration of this data set. Consequently, it is not possible to characterize whether this unit thickens towards the middle of the basin. At the drill sites, unit $g$ has a low-impedance concordant character similar to unit $\mathrm{f}$ and may represent turbidites or mass-flow deposits.

\subsection{BSR and other features}

Near the drill hole, the BSR occurs in the deepest unit, unit $g$ (Figs. 3, 4, and 6). On other lines, it can be traced through units $f$ and e of the lower package. Nowhere can the BSR be identified above disconformity 5 . This may be because the BSR is a weak reflection and, as it nears horizon 5 , it becomes subparallel and therefore impossible to distinguish from the chaotic and discontinuous reflection events of both high and low amplitudes that occur in the deeper parts of unit d (Hutchinson et al., 2008).

In the western, or distal regions of the Casey basin, seismic stratigraphic relations are complicated by lateral changes in the reflection character of the various units. For example, the western occurrence of unit b is characterized by continuous concordant reflections rather than the chaotic character near the drill hole (see "concordant" on Fig. 4). A sharp lateral transition marks the change from chaotic transparent to concordant continuous. Likewise a high-reflection strength, well-laminated localized unit ("ponding?" on Fig. 4) that thins onto disconformity 5 makes it impossible to identify whether discontinuity 5 follows along its top or bottom. These additional facies were not sampled in drilling.

\subsection{Geologic structure}

The east-west and north-south orientations of seismic profiles in the Casey basin reveal that the upper and lower seismic stratigraphic sequences can also be distinguished by unique structural patterns. Lines KC01 and KCO2, which are east-west transects of the entire Casey basin, show that all of the units of the lower sequence are deformed upwards to form an anticlinal structure ('J' in Fig. 4) that divides the basin into two apparent sub-basins. In the vicinity of this anticlinal structure, sediments in units e and $f$ do not thin appreciably and are not obviously truncated along ' $\mathrm{J}$ ', suggesting that the anticlinal structure post-dates their deposition. The ponding unit in Fig. 4 appears to pinch out on 'J' and therefore may be coeval with or follow the formation of the anticlinal geometry. KC01 and $\mathrm{KCO} 2$ are the only two lines that extend far enough west to image the structure, although a number of lines show one side of the anticlinal shape at their extreme westward ends. From these crossings, 'J' both trends and plunges north-northwestward towards the middle of the basin (Fig. 7).

Another anticlinal structure (' $\mathrm{K}$ ' in Fig. 5) trends east-west beneath graben ' $S$ ' at the south end of the Casey basin. This anticlinal structure is essentially orthogonal to 'J' (Fig. 7) and is characterized by a family of faults that offsets the lower-package units (i.e., units e, f, and g). Except for the faults that have been reactivated to form the current graben ' $S$ ' at the seafloor, fault offsets are primarily restricted to horizon 5 and deeper units.

Both of these mapped anticlinal structures at the south end of the Casey basin are former positive-relief features that have either been buried ('J') or inverted (' $K$ '). Structure ' $K$ ' is situated between two modern seafloor structural highs that form the eastern and southeastern rims of the Casey basin and may represent the buried continuation of these two positive-relief features (Fig. 7).

Additional evidence that the lower package is characterized by an older set of faults exists near the East Casey fault zone just north of the JIP drilling location (Fig. 8). This seismic profile shows a series of faults that affects the lower-package units, similar to those observed on Line KC17 (Fig. 5). This older faulting, together with the convergent thinning style of the lower-package units, suggests that a faulted structural high also existed during deposition of units $g$, $f$, and e. On some lines, (e.g., KCO1, Fig. 4), there is no effective separation in the location of the boundary of the basin in the upper and lower package units. However, Line KCO6 at the north end of the survey area demonstrates that there is a slight geographic divergence to the west of the older structural high (' $Y$ ' in Fig. 7) compared to the modern East Casey fault zone. Hence the East Casey fault zone is a reactivation of this older structure, although not exactly in the same location.

\section{Correlation between seismic stratigraphy and drilling results}

In a detailed analysis of LWD data, Lee and Collett (2008) have shown that the general pattern of reflections observed in the 3D seismic data can be reproduced with synthetic seismograms generated from the well logs. In this section, information in the well logs is correlated with the seismic stratigraphy interpreted from the 2D seismic data in the Casey basin. Line KC03 (Fig. 6) crosses $240 \mathrm{~m}$ south of the drill hole.

The gamma-ray log is the most sensitive to lithologic changes and shows variations at distinct intervals in drill hole KC 151-2 (Claypool, 2006). Fig. 6 shows the match between the depthconverted seismic section along line $\mathrm{KCO} 3$ and the gamma-ray and resistivity logs. Horizon $1 \mathrm{~b}$ correlates well with the base of a thick sandy silt section interpreted from the gamma-ray data at 95-110 mbsf. Another spike in the gamma-ray log interpreted as potentially more sandy lithology at $140 \mathrm{mbsf}$ correlates with the lower, chaotic, baselapping portion of unit d. Major disconformity 5 correlates well with another gamma-ray spike at $150 \mathrm{mbsf}$ and is interpreted as a coarser (possibly sandy?) boundary (Claypool, 2006). Unit c contains the thickest interpreted sandy silt section (95-110 mbsf); the spikey gamma-ray signature within unit $c$ indicates that the pattern of convergent thinning of concordant 
Table 2

Casey Basin seismic stratigraphy

\begin{tabular}{|c|c|c|c|}
\hline $\begin{array}{l}\text { Horizon } \\
\text { name }\end{array}$ & $\begin{array}{l}\text { Horizon } \\
\text { description }\end{array}$ & $\begin{array}{l}\text { Unit } \\
\text { name }\end{array}$ & Unit description \\
\hline \multirow[t]{2}{*}{ sf } & Seafloor & & \\
\hline & & $\mathrm{a}$ & $\begin{array}{l}\text { Thin laminated, semi-continuous } \\
\text { reflections parallel to the seafloor, } \\
\text { little thickening towards middle } \\
\text { of basin; } \sim 15 \text { m thick }\end{array}$ \\
\hline \multirow[t]{2}{*}{1} & $\begin{array}{l}\text { Continuous } \\
\text { reflection at base of } \\
\text { unit a }\end{array}$ & & \\
\hline & & b & $\begin{array}{l}\text { Upper - semi-continuous mixed weak and } \\
\text { moderate reflections, convergent thinning, } \\
\text { pinches out to } \sim 10 \text { m thick near drill hole; } \\
>60 \mathrm{~m} \text { near basin middle; Lower - chaotic, } \\
\text { mostly transparent, absence of continuous } \\
\text { reflections, many chaotic diffractions (edges } \\
\text { of slump blocks?); } \sim 50 \mathrm{~m} \text { at drill hole; } \\
\text { thickens to }>100 \mathrm{~m} \text { in middle of basin }\end{array}$ \\
\hline
\end{tabular}

1a Base of chaotic zone of unit b

Strong reflection at base of unit c

One of strongest

reflections in

profile marking

angular

terminations

Base of weak reflections of unit e

$9 \quad$ Top of weakly

reflective unit $\mathrm{f}$

Base of unit
Convergent thinning; semi-continuous concordant reflections; some transparent zones, similar to top of unit b; top is cut into (channelized?) by unit b; 35 m thick near drill holes, 40-50 m thick near middle of basin

Convergent baselapping. Upper convergent thinning, semi-continuous concordant interspersed strong and weak reflections, generally thin $(<30 \mathrm{~m})$ near drill hole; $>100$ m near middle of basin.Lower chaotic with some convergent thinning.

well developed baselap from semi-continuous strong reflections; $10-20 \mathrm{~m}$ thick at drill hole, $>200 \mathrm{~m}$ in middle of basin

Mixed weak

and strong

Weak

$\begin{array}{ll}\text { Strong, continuous } & \text { Seafloor } \\ \text { Mixed strong } & \begin{array}{l}\text { Fine-grained muds of normal } \\ \text { salinity }\end{array}\end{array}$

Strong, continuous

Fine-grained muds; salinity increases from sea water values at top of unit to $\sim 45 \mathrm{ppt}$ about $10 \mathrm{~m}$ down from top of unit

Strong, segmented

Fine-grained muds with coarser, sandier intervals. Overpressured sand at $105 \mathrm{~m}$ (Claypool, 2006) occurs at the base of this interval

Strong

Mixed transparent and strong

Mixed coarse- and fine-grained intervals

Very strong

Convergent thinning, generally low impedance with segments showing strong reflections; semi-continuous; 50-60 m thick near drill hole; $\sim 110$ m thick towards middle of basin

Convergent thinning, semi-continuous, similar to unit e', but generally higher impedance; also contains segments showing strong reflections; $\sim 30 \mathrm{~m}$ near drill hole, $\sim 90 \mathrm{~m}$ thick towards middle of basin

Convergent thinning, low-impedance continuous, concordant reflections; $<100 \mathrm{~m}$ near drill hole; $\sim 120 \mathrm{~m}$ thick near middle of basin
Weak

Fine-grained muds; highresistivity spikes in lower third indicate probable hydrate occurrence

Weak

Strong

Fine-grained muds; fewer resistivity spikes indicate lower-saturation hydrate occurrences

Weak

Very weak

\section{Strong}

Mixed weak and strong
Fine-grained muds, resistivity spikes in upper third indicate probable hydrate occurrence

Fine-grained muds, elevated salinity, BSR occurs in this section at small resistivity anomaly
Mixed chaotic (transparent) and segments of semi-continuous weak to strong amplitude reflections; chaotic zones have wavy and short dipping segments; strong continous reflections are infrequent; base of unit not picked in interpretation
Interpretation

Hemipelagic drape, highstand conditions, Holocene

Conformity

Mass wasting deposition with some interspersed concordant deposition; absence of baselap suggests minimal subsidence.

Disconformity, locally incised

Mixed deposition (e.g., hemipelagic or low-density turbidites); minor or no subsidence; fine-grained

Conformity

Mixed mass wasting during period of rapid subsidence and infilling; large sediment supply, sandprone (primarily lowstand)

Major disconformity

Predominantly mud containing coarser sediment to account for segments of strong reflections

Conformity

Predominantly coarser (silt? sand?) to explain higher reflectivity, but also containing finer muds or clays

\section{Conformity}

Hemipelagic deposition; fine-grained, highstand

Conformity

Mixed mass wasting, mud dominated with some coarser material (high amplitudes) 


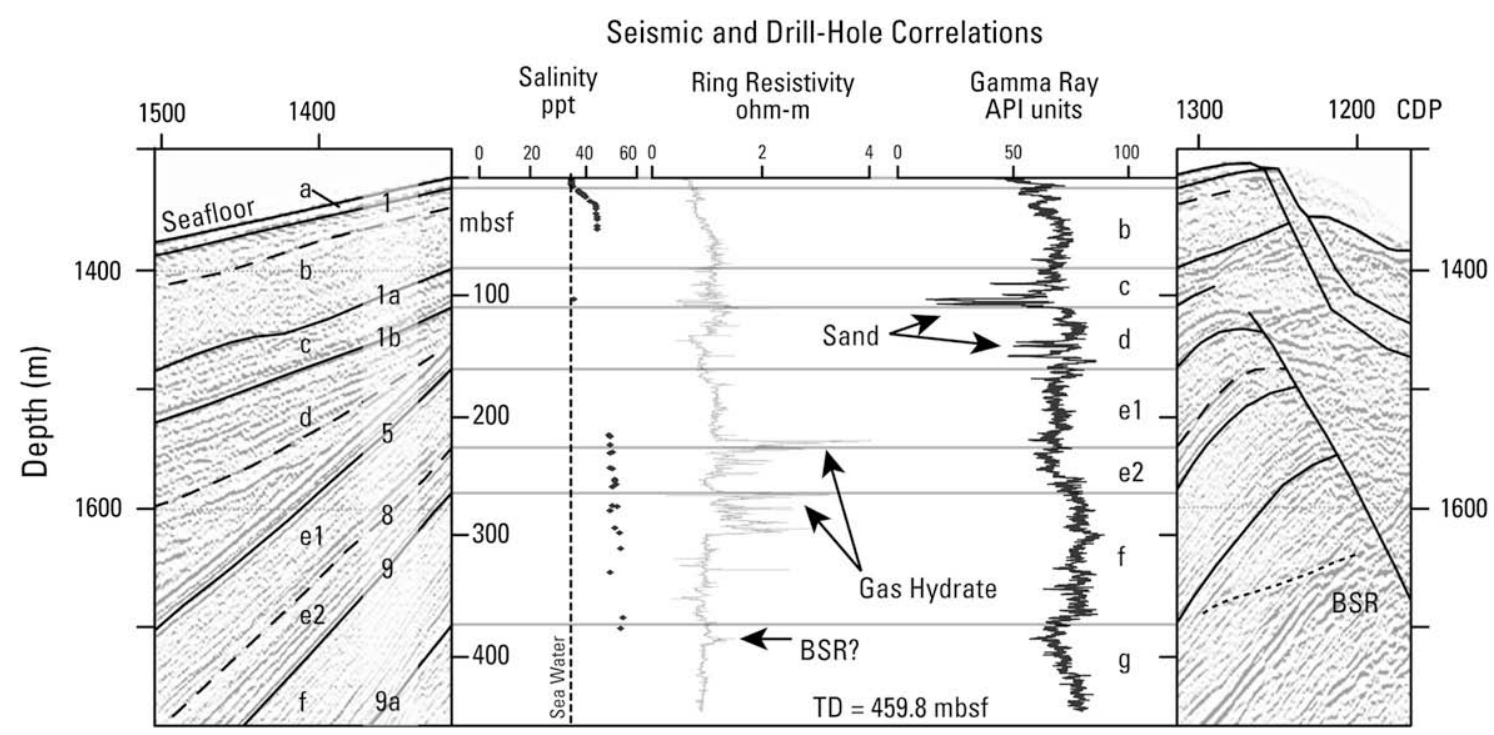

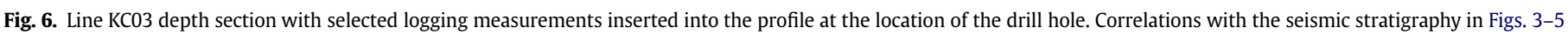
are shown. Salinity and logging data are given in and described by Claypool et al. (2006).

reflections can be explained by alternating coarser and finer-grained intervals. In units e, $\mathrm{f}$, and $\mathrm{g}$, large low gamma-ray spikes indicative of sandier layers are absent, indicating that these units are primarily a clay-dominated sedimentary section (Claypool, 2006).

The ring resistivity measurements delineate a zone of elevated resistivity anomalies (Fig. 6; $\sim 3 \Omega \mathrm{m}$ compared to background resistivity of $1 \Omega \mathrm{m}$; Claypool, 2006) between $\sim 220$ and 300 mbsf. This zone of elevated resistivity correlates with parts of units e and f. A slight resistivity anomaly may characterize the depth of the BSR at 392 mbsf (Lee and Collett, 2008). Lee and Collett (2008) infer a very small reduction in water saturations at the BSR and therefore low saturations of gas hydrate and free gas, an interpretation that is consistent with the BSR appearing as a very weak reflection at the drill hole on line KCO3.

\section{Geological evolution}

The geological evolution inferred from these structural and stratigraphic patterns is that the Casey basin contains at least three episodes of evolution resolvable in the high-resolution multichannel data. In the oldest episode, inferred from units $\mathrm{g}$, f, and e, a structural high existed along the eastern and southern margins of the basin (along ' $\mathrm{Y}$ ' and ' $\mathrm{K}$ ' of Fig. 7). Convergent thinning of the stratal style of units e and $f$ towards these highs is the basis for inferring their positive relief. The lack of extreme thinning or thickening suggests that units e and f were deposited during times of relative stability of the basin. The low-amplitude nature of most reflections in these units suggests deposition was dominated by fine-grained turbidites and hemipelagic sediments.

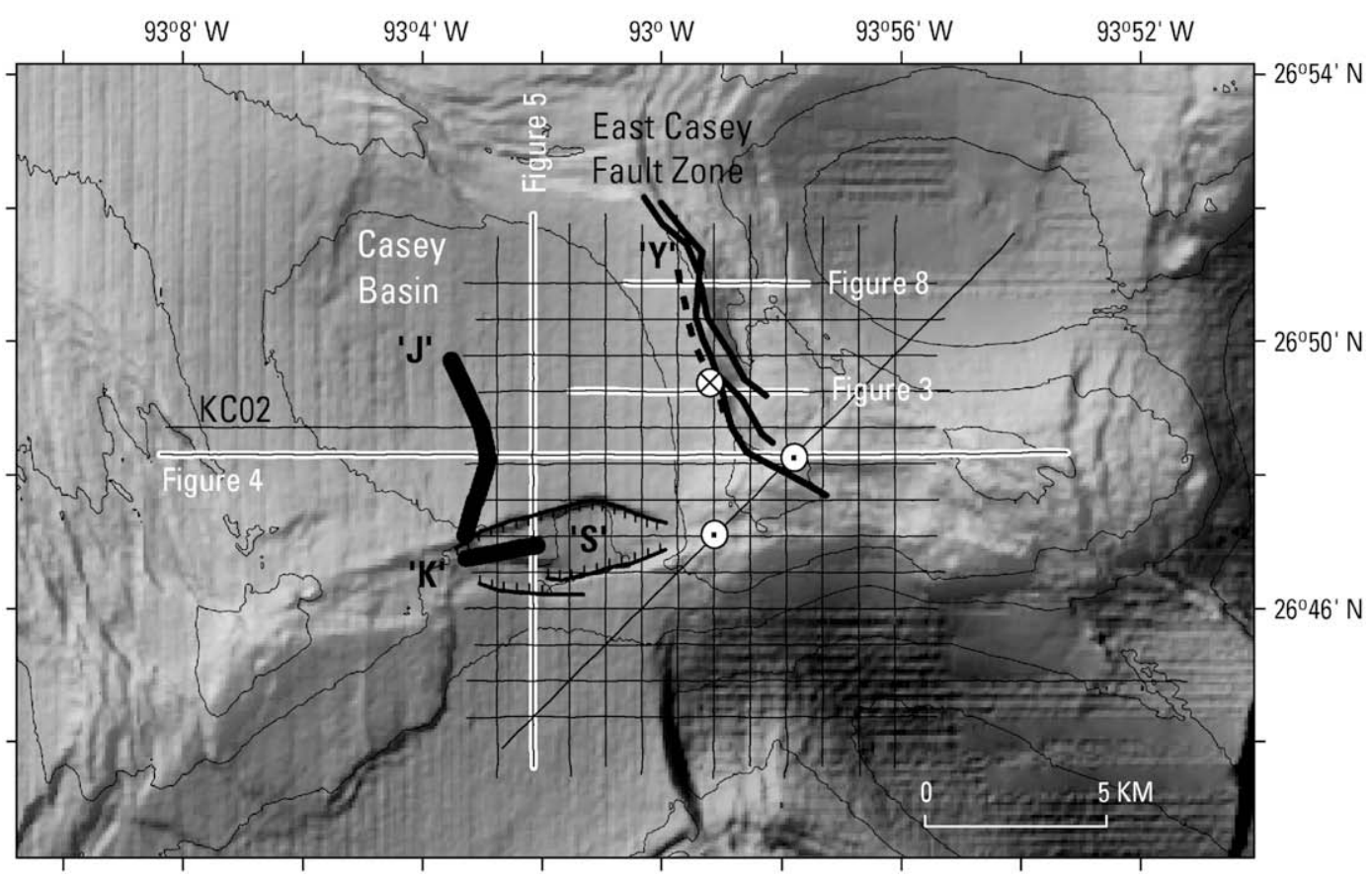

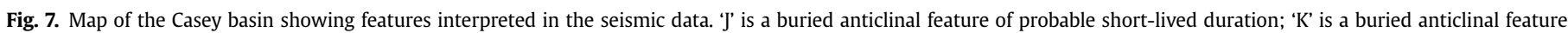

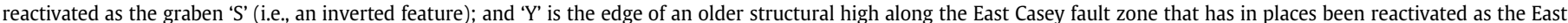
Casey fault. 


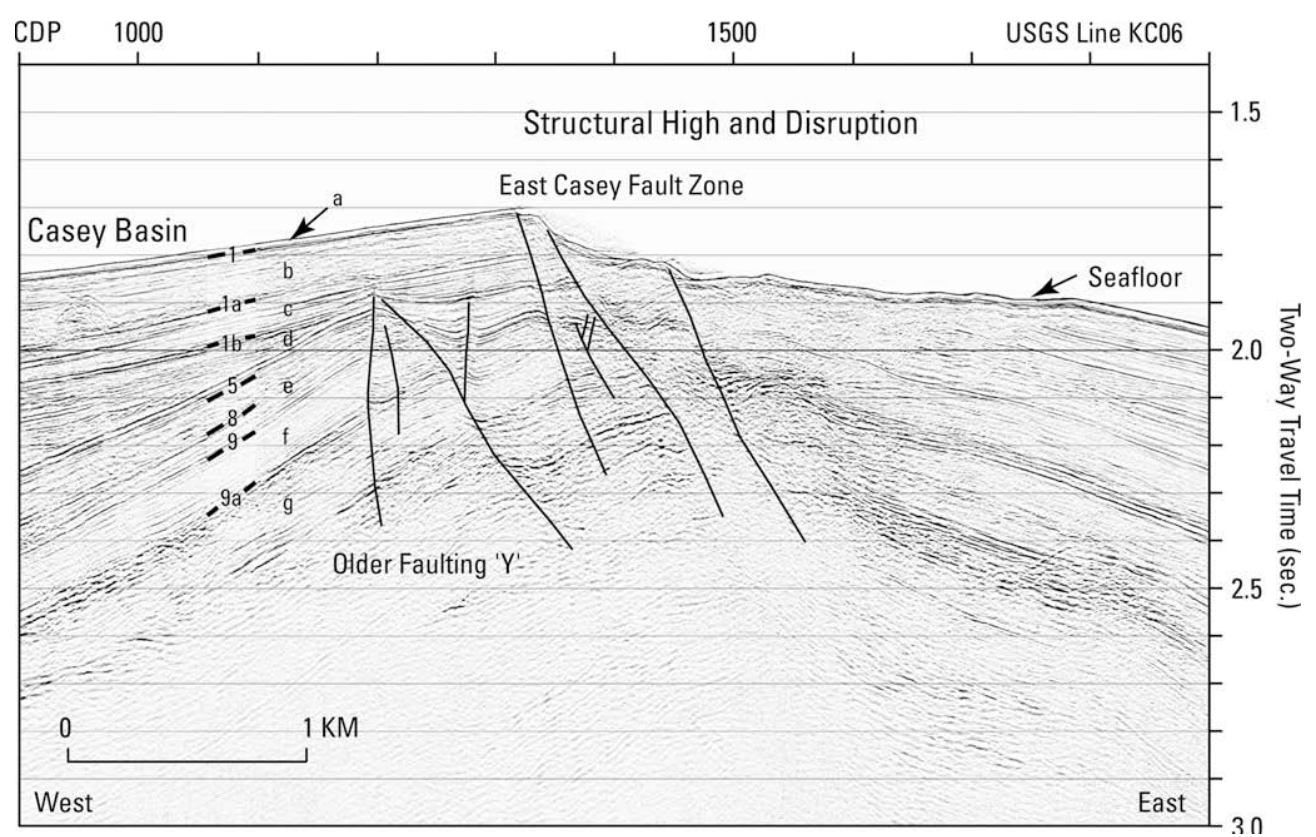

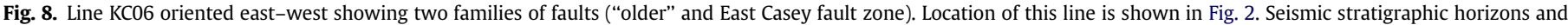
units identified in Figs. 3-5 and described in Table 2.

Horizon 5 and overlying unit d define a second episode of formation in which a major change occurred (Figs. 3-6). The baselapping geometry of unit $\mathrm{d}$ and the formation of anticlinal structure ' $\mathrm{J}$ ' at and along horizon 5 suggests that the basin experienced significant vertical motions-subsidence to create the accommodation space that unit d eventually filled and uplift in the central part of the basin to form anticlinal structure 'J.' The chaotic depositional style of unit d indicates erratic deposition, multiple hiatuses, and probably frequent mass wasting events. Large amounts of sediment filled the space above horizon 5 and eventually buried anticlinal structure "J". The basin returned to a convergent thinning and convergent baselapping geometry during deposition of the upper part of unit $d$. The progression suggests a transition from gravitydriven mass wasting to sheet sand/fan deposition to channelized mixed-grained deposits to bypass deposition.

The stratal and structural relations of unit $d$ are consistent with a period of ponding of sediment (Prather et al., 1998; Winker and Booth, 2000), in which the intraslope basin acts as a trap first for mass wasting deposits and subsequently for submarine fan material that would otherwise move downslope. These ponded facies assemblages are often characterized by sand-dominated turbidites (Winker and Booth, 2000). The sand units inferred at 140 and 150 mbsf in the logging data are probably the distal, thinned fringe of much thicker sand units that were deposited in the middle of the basin within unit $d$. The sandy intervals logged in unit c may represent the last or youngest parts of the sand-dominated ponded facies assemblage within the Casey basin. By the time that horizon $1 \mathrm{a}$ formed at the top of unit $\mathrm{c}$, the basin had mostly filled to its sill at the south end. The irregular surface on horizon 1a (Fig. 4) suggests subsequent downcutting and removal of material.

During the final and youngest episode of basin formation, coincident with deposition of units $\mathrm{a}$ and $\mathrm{b}$, the basin continued to accumulate deposits, but the convergent thinning of concordant reflections (top of unit b) and the draping style (unit a) indicate that the vertical motions are much subdued compared to the second episode of formation. This facies succession suggests progression from fine-grained turbidite deposition during unit b time to hemipelagic sedimentation during unit a time. Offset of the seafloor along the East Casey fault zone indicates that vertical motion continues along the structural high rimming the basin. Similarly, the graben structure at the south end ('S' in Figs. 5 and 7) offsets the seafloor and indicates that extremely localized subsidence is deepening the southern end of the basin. These youngest deposits appear to represent a transition to the bypass facies assemblage, in which sediments are not trapped in the basin, but bypass it to accumulate further downslope (Prather et al., 1998; Winker and Booth, 2000).

\section{Discussion}

\subsection{Occurrence of gas hydrate}

Although gas hydrate was not physically recovered during the Gulf of Mexico drilling program, indirect evidence for its occurrence in situ (e.g., cold spots in the cores and elevated electrical resistivity anomalies) suggested its probable occurrence from $\sim 220$ to $300 \mathrm{~m}$ in KC 151-2 (Claypool, 2006). This corresponds to portions of units e and $\mathrm{f}$ in the seismic stratigraphy, units that are interpreted as fine-grained muds and clays based on gamma-ray logging data. Using the resistivity measurements and the Archie relation to quantify the amount of gas hydrate, Lee and Collett (2008) estimated that the top of this interval from 220-230 mbsf contained significant gas hydrate, with several thin peaks up to $40 \%$ saturation of the pore space. In the rest of the gas hydrate-bearing section, variability was large, and estimates of less than $10 \%$ saturation were common. Sinusoidal patterns in the resistivity-at-thebit (RAB) imaging for the KC 152-2 hole (Fig. 9) further indicate that this interval from 220 to 300 mbsf contains numerous, near-vertical structures interpreted as fractures (Cook et al., 2008). The fracture voids are the most likely explanation for the localized elevated concentrations of gas hydrate (Cook et al., 2008). Fractures within clay-dominated hydrate-bearing sediments have been observed in the Blake Ridge (Dillon et al., 1997; Rowe and Gettrust, 1993). The Gulf of Mexico data are consistent with these fractures being a common feature associated with hydrates in fine-grained sediments.

There are currently three conceptual models for the formation and location of elevated concentrations of gas hydrate. One of the 


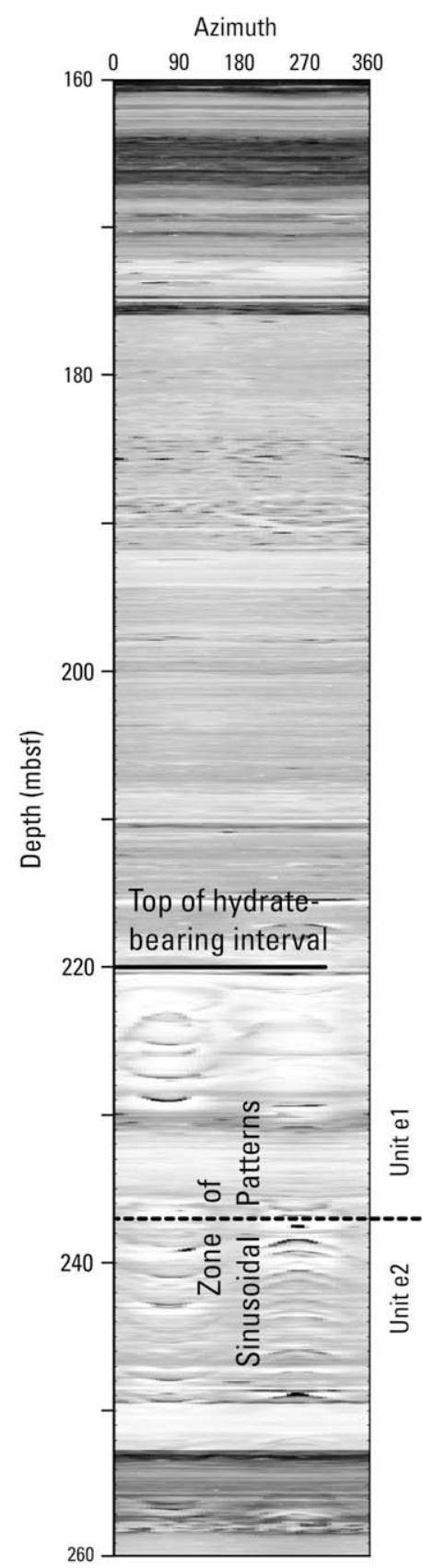

Fig. 9. RAB images showing the high-resistivity interval below $220 \mathrm{mbsf}$, which is below the major disconformity (horizon 5 ). The sinusoidal patterns seen in the RAB images are consistent with steeply dipping fracture surfaces. These fractures are not evident in the shallower units.

earliest models leads to hydrate concentrations that increase with depth to a maximum near the BSR (Dillon et al., 1980; Hyndman and Davis, 1992; Hyndman and Spence, 1992; Kvenvolden, 1990). This explanation has been invoked to explain hydrate concentrations on the Blake Ridge, a mobile sediment drift deposit on a passive margin (Holbrook, 2001; Korenaga et al., 1997) and in the Cascadia accretionary wedge on an active margin (Hyndman and Davis, 1992; Hyndman and Spence, 1992). In this model, hydrate becomes concentrated near the base of the HSZ through time either by continuing sedimentation (Blake Ridge) or uplift (Cascadia accretionary wedge), both processes that recycle methane near the BSR as the BSR migrates to shallower depths through time. Higher concentrations of gas hydrate near the base of the stability zone are also consistent with the results of steady-state numerical models for upward migration of methane through homogeneous sediments (Xu and Ruppel, 1999), with the higher concentration of hydrate near the base of the HSZ being a consequence of the morphology of the methane solubility curve between this depth and the seafloor (Nimblett and Ruppel, 2003). The JIP studies described in this paper in the northern Gulf of Mexico inferred that maximum concentrations of hydrate within the northern Gulf of Mexico study areas occur well above the BSR, indicating that a simple steady-state evolutionary model does not readily apply there.

A second model, which has grown out of the results of studies in permafrost settings, suggests that hydrate is concentrated along coarse, sand-rich horizons that might be located anywhere within the HSZ and contain maximum hydrate concentrations greater than 50 to $70 \%$ or pore space (Collett, 2002; Collett and Dallimore, 2000; Dallimore and Collett, 2005). Recently, this model was demonstrated to also be applicable to some marine environments, with high saturations of gas hydrate recovered in sand-rich units above the BSR in the Nankai trough off Japan (Baba and Yamada, 2004; Fujii et al., 2005), offshore Oregon (Trehu et al., 2004) and offshore Vancouver, British Columbia (Expedition 311 Scientists, 2006; Reidel et al., 2006). In the KC 151-2 hole, the sandy silt sections identified as part of units $\mathrm{c}$ and $\mathrm{d}$ appear to lack significant hydrate, based on the lack of resistivity anomalies at those depths. However, these more sandy units at KC 151-2 are not the type of cleaner, coarser, and/or more permeable sands that have been found to contain significant gas hydrate at other locations and may be disconnected from a source of gas charge as well. This may explain why these units may not have concentrated gas hydrate, while deeper mud/clay-rich sections of units e and f do.

The third model accounts for the dynamic nature of the gas HSZ by identifying and emphasizing the pathways and concentrations of methane-rich fluids that move through the sedimentary section (Nimblett and Ruppel, 2003). These pathways can serve to concentrate gas hydrate in porous media (i.e., the sand model), or in secondary porosity, such as fractures or faults. Researchers in the Gulf of Mexico have long suggested that gas hydrate at seafloor exposures and in near-seafloor cores is probably concentrated around sites of fluid venting (MacDonald et al., 2003; Roberts, 1995; Sager et al., 2003, 2004; Sassen et al., 2001). In a variation of this model, vents evolve from high flux (mud volcanos) to intermediate flux (gas hydrate-bearing) to low flux (primarily carbonate hard grounds) (Roberts, 2001; Roberts and Carney, 1997). Recently, fault pathways have been re-emphasized as the sites of gas hydrate concentration (e.g., focused flow model of Max et al., 2006). Common to all of these explanations is the presence of pathways along which fluids can migrate and cause gas hydrate to be concentrated as these fluids move into the HSZ. The gas hydrate inferred at KC 151-2 is most compatible with this third, pathways-based model because of their presumed association with fracture porosity in the 220-300 mbsf interval (e.g., Cook et al., 2008). The seismic data are insufficient to resolve steeply dipping structures such as fractures and are therefore not appropriate for mapping the distribution of the fracture networks. However, like the older family of faults, they appear to only occur in the lower package of units based on the RAB imagery (Cook and Goldberg, 2006) and therefore are not conduits for fluids to migrate into the shallower sand units.

\subsection{Source of sands in the Casey basin}

The sands identified in KC 151-2 are porous units within the HSZ. Although they were not saturated with gas hydrate, their presence supports the hypothesis that shallow sands may be more common in the marine environment of the continental slope and could be reservoirs for elevated gas hydrate saturations (Johnson 
and Smith, 2006). The question, then, is where do the sands come from and what is their likely form?

The location of the Casey basin provides a context for interpreting the source of sand associated with units $\mathrm{c}$ and $\mathrm{d}$. The basin is downslope from the Late Pleistocene western depocenter of the Mississippi River, a fluvial deltaic system at the edge of the continental shelf off western Louisiana (Berryhill et al., 1986; Coleman and Roberts, 1988). This shelf-edge delta developed during a sea level low stand (i.e., during a glacial interval) and is dated between $320 \mathrm{ka}$ and $70 \mathrm{ka}$ (Winker and Booth, 2000). The sand of this shelfedge delta is the presumed source of multiple intraslope fans that are well mapped on the upper continental slope of the northern Gulf (Prather et al., 1998; Winker and Booth, 2000). This delta was also the source of active sediment transport down the Alaminos, Keathley, and Bryant canyons. Fig. 10 shows the location of the maximum progradation of the delta complex, together with the active transport pathways down the slope as mapped by Winker and Booth (2000). An unconnected pathway fragment between the Keathley and Bryant canyon pathways is directly upslope from the Casey basin and is a logical source of sand transport into this basin.

The 1-km spacing of seismic lines precludes mapping active or subsurface channels or depositional packages of dimensions smaller than the line spacing, and the geographic coverage of lines is insufficient to connect channel pathways from the upslope fragment to the Casey basin. Hence, this correlation remains to be tested. Only one core sample was collected in hole KC 151-3 at the level of units c and d, so age data from drilling are not likely to further constrain the age. If correct, our interpretation suggests that units $d$ and c, with baselapping and convergent geometries, are fan systems that were supplied while the western shelf-edge delta was active. The youngest units mapped, $b$ and $a$, therefore represent the latest Pleistocene and Holocene, respectively. This interpretation is consistent with regional understanding of the age of the youngest sedimentary deposits (Coleman et al., 1991).
The shallow seismic stratigraphy of minibasins in the northern Gulf can rarely be correlated between basins (Beauboeuf and Friedmann, 2000; Prather et al., 1998; Winker and Booth, 2000), indicating the importance of local factors (e.g., salt tectonism, mass wasting, sediment sources) in controlling depositional style and shape. If the minibasins mapped on the upper slope can serve as models of deposition for those of the middle and lower slope, such as the Casey basin, then the sand units are most likely composed of deposits associated with intraslope fans, channel environments, and mass-flow units (Prather et al., 1998). Implicit in these active depositional environments is considerable lateral and vertical heterogeneity caused by the diversity of depositional processes that occurred in the basin.

The challenge in finding concentrated gas hydrate saturations in the northern Gulf of Mexico will be to find those deposits that contain massive, laterally extensive sands, such as might be transported through canyon pathways, and for these sands to be located in regions where fluid conduits, such as faults, fractures, or vents, can transport methane-rich fluids into the sand deposits or where the permeable sands straddle the base of the HSZ and themselves act as the conduits for methane-rich fluids. The dilemma in much of the northern Gulf is that currently active faults generally lie along the edges of the minibasins, near where the distal edges of sandy deposits are thinnest and are likely to be most discontinuous (i.e., of marginal reservoir quality). This depositional style does not preclude situations in which gas hydrate can concentrate in coarse units, but it emphasizes the need to understand lithologies, sources, and fluid conduits in any model that predicts gas hydrate location (Davie and Buffett, 2001; Nimblett and Ruppel, 2003; Xu and Ruppel, 1999). One intriguing observation in the Gulf is the existence of older faults (e.g., ' $\mathrm{K}$ ' in Fig. 7) that could provide transport pathways within the deeper portions of basins where the depositional units are less thinned and discontinuous. Whether these deeper pathways tap into gas sources and can serve as conduits for fluids migrating into the shallower units remains to be tested.

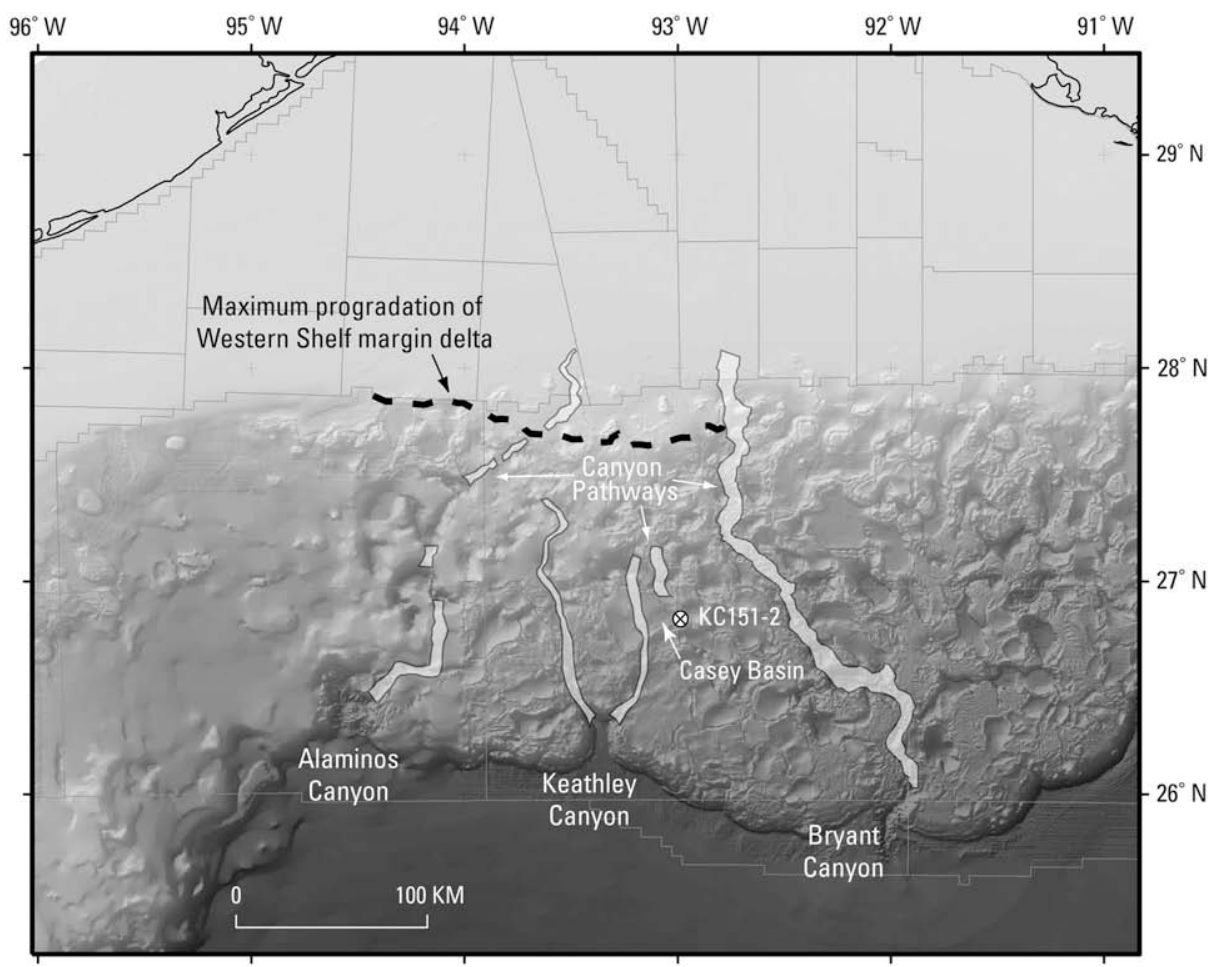

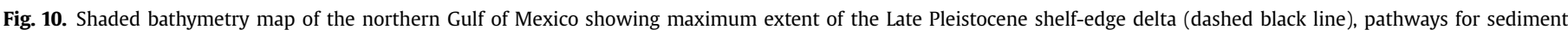

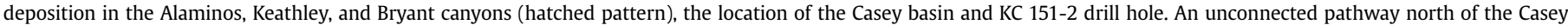
basin might have been the source for sands identified in the KC 151-2 drill hole. 


\section{Conclusions}

High-resolution 2D data from near the JIP Keathley Canyon KC 151-2 drill site in the northern Gulf of Mexico provide the opportunity to place the borehole-derived information within the context of the geologic setting. The drill site is located on the uplifted southeastern edge of an intraslope minibasin, the Casey basin, at $1335 \mathrm{~m}$ water depth. Seismic stratigraphic analysis is used to divide the uppermost kilometer of sediments into 7 stratal units. A major disconformity (horizon 5) with pronounced baselapping geometry stands out as the most prominent surface in the data and separates the 7 stratal units into two sequences. The three units identified beneath horizon 5 correlate with fine-grained muds in the drilling. Gas hydrates are associated with two of these deeper, older units and occupy near-vertical fractures or possibly pore space in cleaner lithologies (e.g., Cook et al., 2008). An older family of faults also occurs within these three older units. The near-vertical fractures and the older generation of faults may be related, but the multichannel data are not of sufficient resolution to demonstrate such an association.

At the time of horizon 5, the Casey basin experienced large vertical motions that resulted in the hiatus marked by horizon 5 and in significant infilling and ponding of sediment in units $c$ and $\mathrm{d}$ above the disconformity. Correlation of the seismic stratigraphic analysis with borehole results shows that units $\mathrm{c}$ and $\mathrm{d}$ are probably intercalated sands and muds that represent the thinned and distal edges of thicker sequences in the middle of the basin. These units are interpreted to represent turbidite and channel fill sequences that have lateral and vertical heterogeneity and variable reflection character. When compared to the broader evolution of the Gulf, these units probably correlate with deposits derived from the western depocenter and shelf-edge delta of the Mississippi River that was most active in Late Pleistocene time and that was the probable cause of sediment loading and salt withdrawal in this latestage evolution of the basin.

The youngest units, $a$ and $b$, mark a return to more subdued vertical motions, a fine-grained depositional environment, and a more stable basin. Unit a, which occurs at and beneath the seafloor, consists of hemipelagic drape. Offset of the seafloor along faults on the salt-cored structural high $\sim 260$ m east of the drill site indicates fault motion has continued into recent times. The basin is currently nearly filled with sediment, with less than $20 \mathrm{~m}$ depth separation between the southern sill at $1460 \mathrm{~m}$ compared to the deepest point in the basin at 1470-1480 m. Hence the Casey basin is transforming from a ponded facies basin in the Late Pleistocene to one in which downslope transport will primarily bypass the basin. The southern sill is also subsiding as part of a graben structure, masking the older structural high that caused the ponding of the older units.

The heterogeneity and complexity of the site indicate the challenges in identifying zones in which gas hydrate will be most concentrated. The lack of evidence for hydrate in the shallower coarse-grained deposits suggests that the fracture network within the fine-grained muds does not provide conduits for fluid migration to shallower units. Therefore, at this site, the existence of sandier units within the HSZ is not sufficient to concentrate gas hydrate despite the presence of gas hydrate in lower permeability, clay-rich units deeper in the section.

\section{Acknowledgements}

Partial support for the field and interpretive aspects of this project were provided by the Department of Energy, National Energy Technology Lab (NETL). WesternGeco (Schlumberger) generously provided velocity information for converting travel times to depths. We thank E. Jones and the JIP partners for encouragement and insight during multiple meetings and discussions. W. Shedd,
J. Hunt, and colleagues at MMS were helpful in advising on trackline locations and permitting for the field program. N. Satyavani helped with initial mapping of stratal boundaries. We also thank the many colleagues who clarified and helped in understanding the complicated occurrence of gas hydrate in the Gulf of Mexico. This paper has been improved by reviews by W. Dillon, W. Barnhardt, $\mathrm{W}$. Shedd and an anonymous reviewer.

\section{References}

Anderson, R.K., Scalan, R.S., Parker, P.L., Behrens, E.W., 1983. Seep oil and gas in Gulf of Mexico slope sediment. Science 222, 619-621.

Andreassen, K., Hart, P.E., Mac Kay, M., 1997. Amplitude versus offset modeling of the bottom simulating reflection associated with submarine gas hydrates. Mar. Geol. 137, 25-40.

Baba, K., Yamada, Y., 2004. BSRs and associated reflections as an indicator of gas hydrate and free gas accumulation: an example of accretionary prism and forearc basin system along the Nankai Trough, off central Japan. Res. Geol. 54, $11-24$

Bangs, N.L., Sawyer, D.S., Golovchenko, X., 1993. Free gas at the base of the gas hydrate zone in the vicinity of the Chile Triple Junction. Geology 21, 905-908.

Beauboeuf, R.T., Friedmann, S.J., 2000. High-resolution seismic/sequence stratigraphic framework for the evolution of Pleistocene intra slope basins. Western Gulf of Mexico: depositional models and reservoir analogs. In: Proceedings of the GCSSEPM Foundation 20th Annual Research Conference, Deepwater Reservoirs of the World, pp. 40-60.

Berryhill, H.L., Suter, J.R., Hardin, N.A., 1986. Late Quaternary facies and structure, northern Gulf of Mexico: interpretations from seismic data. AAPG Stud. Geol. 23, 1-289.

Bird, D.E., Burke, K., Hall, S.A., Casey, J.F., 2005. Gulf of Mexico tectonic history: hotspot tracks, crustal boundaries, and early salt distribution. AAPG Bull. 89 (3), 311-328.

Booth, J.S., 1979. Recent history of mass wasting on the upper continental slopes, northern Gulf of Mexico, as interpreted from the consolidation states of the sediment. In: Doyle, L.J., Pilkey Jr., O.H. (Eds.), Geology of Continental Slopes. SEPM Special Publication, vol. 27, pp. 153-164.

Brooks, J., Kennicutt II., M.C., Fay, R.R., McDonald, T.J., Sassen, R., 1984. Thermogenic gas hydrates in the Gulf of Mexico. Science 225, 409-411.

Bryant, W.R., Bryant, J.R., Feeley, M.H., Simmons, G.R., 1990. Physiographic and bathymetric characteristics of the continental slope, Northwest Gulf of Mexico. Geo Mar. Lett. 10, 182-199.

Claypool, G.E., 2006. Gulf of Mexico Gas Hydrate Joint Industry Project (GOMJIP), 2005. The Cruise of the Drilling Vessel Uncle John, Mobile, Alabama to Galveston, Texas, Atwater Valley Blocks 13/14 and Keathley Canyon Block 151, 17 April to 22 May 2005 Available from: http://www.netl.doe.gov/technologies/ oil-gas/publications/Hydrates/reports/GOMJIPCruise05.pdf.

Clennell, M.B., Hovland, M., Booth, J.S., Henry, P., Winters, W.J., 1999. Formation of natural gas hydrates in marine sediments 1 . Conceptual model of gas hydrate growth conditioned by host sediment properties. J. Geophys. Res. 104, 2298523003.

Coleman, J.M., Roberts, H.H., 1988. Sedimentary development of the Louisiana continental shelf related to sea level cycles: part I - sedimentary sequences and part II - seismic stratigraphy. Geo Mar. Lett. 8, 63-119.

Coleman, J.M., Prior, D.B., Lindsay, J.F., 1983. Deltaic influences on shelf edge instability processes. In: Stanley, D.J., Moore, G.T. (Eds.), The Shelf Break; Critical Interface on Continental Margins. SEPM Special Publication, vol. 33, pp. $121-138$.

Coleman, J.M., Roberts, H.H., Bryant, W.R., 1991. Late Quaternary sedimentation. In: Salvador, A. (Ed.), The Gulf of Mexico Basin. The Geology of North America, vol. J. GSA, Boulder, CO, pp. 325-352.

Collett, T.S., 2002. Energy resource potential of natural gas hydrates. AAPG Bull. 86, 1971-1992.

Collett, T.S., Dallimore, S.R., 2000. Permafrost-associated gas hydrate. In: Max, M.D. (Ed.), Natural Gas Hydrate In Oceanic and Permafrost Environments. Kluwer, Dordrecht, pp. 43-60.

Cook, A., Goldberg, D., 2006. ChevronTexaco JIP Well-log Data Available from: https://cpln-www1.chevron.com/cvx/gasjip.nsf/WhatsNew/2FEABBD232E245D 788257174000A9330?opendocument.

Cook, A.E., Goldberg, D., Kleinberg, R.L., 2008. Fracture-controlled gas hydrate systems in the northern Gulf of Mexico. Mar. Petr. Geol. 25, 932-941.

Cooper, A.K., Hart, P.E., 2003. High-resolution seismic-reflection investigation of the northern Gulf of Mexico gas-hydrate-stability zone. Mar. Petr. Geol. 19, 1275-1293.

Dai, J., Xu, H., Snyder, F., Dutta, N., Herron, D., 2004. Detection and estimation of gas hydrates using rock physics and seismic inversion; examples from the northern deepwater Gulf of Mexico. The Leading Edge 23, 60-66.

Dallimore, S.R., Collett, T.S., 2005. Summary and implications of the Mallik 2002 gas hydrate production research well program. In: Dallimore, S.R., Collett, T.S. (Eds.), Scientific Results from the Mallik 2002 Gas Hydrate Production Research Well Program, Mackenzie Delta, Northwest Territories, Canada. Bull. Geol. Surv. Can. $585,1-36$. 
Davie, M.K., Buffett, B.A., 2001. A numerical model for the formation of gas hydratebelow the seafloor. J. Geophys. Res. 106, 497-514.

Diegel, F.A., Karlo, J.F., Schuster, D.C., Shoup, R.C., Tauvers, P.R., 1995. Cenozoic structural evolution and tectono-stratigraphic framework of the northern Gulf Coast continental margin. In: Jackson, M.P.A., Roberts, D.G., Snelson, S. (Eds.), AAPG Memoir, 65, pp. 109-151.

Dillon, W.P., Paull, C.K., 1983. Marine gas hydrates. II: geophysical evidence. In: Cox, J.L. (Ed.), Natural Gas Hydrates. Butterworth, Boston, pp. 73-90.

Dillon, W.P., Grow, J.A., Paull, C.K., 1980. Unconventional gas hydrate seals may trap gas off Southeast U.S. Oil Gas J. 78 124,126,129-130.

Dillon, W.P., Holbrook, W.S., Drury, R.M., Gettrust, J.F., Hutchinson, D.R., Booth, J.S., Taylor, M., Judzis, A., 1997. Faulting of gas-hydrate-bearing marine sediments: contribution to permeability. In: Proceedings of the Offshore Technology Conference, 29, pp. 201-209.

Divins, D.L., Metzger, D., 2004. NGDC Coastal Relief Model Available from: http:// www.ngdc.noaa.gov/mgg/coastal/coastal.html.

Dix, C.H., 1955. Seismic velocities from surface measurements. Geophysics 20, 68-86.

Ewing, T.E., 1991. Structural framework. In: Salvador, A. (Ed.), The Gulf of Mexico Basin. The Geology of North America, vol. J. GSA, Boulder, CO, pp. 31-52.

Expedition 311 Scientists, 2006. Expedition 311 summary. In: Riedel, M., Collett, T.S., Mallone, M.J., Expedition 311 Scientists (Eds.), Proc. IODP, 311, doi:10.2204/iodp. proc.311.101.2006. http://iodp.tamu.edu/publications/exp311/101/101_.htm.

Fujii, T., Kawasaki, M., Nakamizu, M., Namikawa, T., Ochiai, K., Okui, T., Tsuji, Y., 2005. Modes of occurrence and accumulation mechanism of methane hydrate result of METI exploratory test wells "Tokai-oki to Kumano-nada". In: Fifth International Conference on Gas Hydrates, Trondheim, Norway, pp. 974979.

Hart, P.E., Hutchinson, D.R., Lee, M.W., 2005. High-resolution Multichannel Seismicreflection Data Acquired in the Northern Gulf of Mexico, 2003. U.S. Geological Survey Open File Report 2005-1411 Available from:. http://pubs.usgs.gov/of/ 2005/1411/.

Holbrook, W.S., 2001. Seismic studies of the Blake Ridge: implications for hydrate distribution, methane expulsion, and free gas dynamics. In: Paull, C.K., Dillon, W. (Eds.), Natural Gas Hydrates: Occurrence, Distribution and Detection. American Geophysical Union Monograph, vol. 124, pp. 235-256. Washington, D.C.

Hutchinson, D.R., Hart, P.E., 2004. Cruise report for G1-03-GM USGS Gas Hydrates cruise, R/V Gyre, 1-14 May, 2003, Northern Gulf of Mexico, U.S. Geological Survey Open File Report 03-474, 103 pp.

Hutchinson, D.R., Hart, P.E., Ruppel, C.D., Snyder, F., Dugan, B., 2008. Seismic and thermal characterization of a bottom simulating reflection in the northern Gulf of Mexico. In: Collett, T.S., Johnson, A., Knapp, C., Boswell, R. (Eds.), Natural Gas Hydrates: Energy Resources, Potential and Associated Geologic Hazards. AAPG Special Publication.

Hyndman, R.D., Davis, E.E., 1992. A mechanism for the formation of methane hydrate and seafloor bottom-simulating reflectors by vertical fluid explusion. J. Geophys. Res. 97, 7025-7041.

Hyndman, R.D., Spence, G.D., 1992. A seismic study of methane hydrate marine bottom simulating reflectors. J. Geophys. Res. 97, 6683-6698.

Johnson, A.H., Smith, M.A., 2006. Gas hydrate E\&P: dispelling the myths. E\&P, Hart Energy Publishing, September, 3 pp. <http://www.epmag.com/archives/technologySections/6247.htm>.

Korenaga, J., Holbrook, W.S., Singh, S., Minshull, T., 1997. Natural gas hydrates on the southeast U.S. margin: constraints from full waveform and travel time inversions of wide-angle seismic data. J. Geophys. Res. 102, 15345-15365.

Kvenvolden, K.A., 1990. Gas hydrates of outer continental margins. AAPG Bull. 74 (5), 698.

Kvenvolden, K.A., 1993. Gas hydrates - geological perspective and global change. Rev. Geophys. 31, 173-187.

Lee, G.H., Watkins, J.S., Bryant, W.R., 1996. Bryant Canyon Fan System: an unconfined, large river-sourced system in the northwestern Gulf of Mexico. AAPG Bull. 80, 340-358.

Lee, M.W., Collett, T.S., 2008. Integrated analysis of well logs and seismic data to estimate gas hydrate concentrations at Keathley Canyon, Gulf of Mexico. Mar. Petr. Geol. 25, 924-931.

MacDonald, I.R., Guinasso Jr., N.L., Ackleson, S.G., Amos, J.F., Duckworth, R., Sassen, R., Brooks, J.M., 1993. Natural oil slicks in the Gulf of Mexico visible from space. J. Geophys. Res. 98, 16,351-16,364.

MacDonald, I.R., Guinasso, N.L., Sassen, R., Brooks, J.M., Lee, L., Scott, K.T., 1994. Gashydrate that breaches the sea floor on the continental slope of the Gulf of Mexico. Geology 22, 699-702.

MacDonald, I.R., Reilly Jr., J.F., Best, S.E., Venkataramaiah, R., Sassen, R., Guinasso Jr., N. L., Amos, J., 1996. Remote sensing inventory of active oil seeps and chemosynthetic communities in the northern Gulf of Mexico. In: Schumacher, D. Abrams, M.A. (Eds.), AAPG Memoir, 66, pp. 27-37.

MacDonald, I.R., Sager, W.W., Peccini, M.B., 2003. Gas hydrate and chemosynthetic biotain mounded bathymetry at mid-slope hydrocarbon seeps; northern Gulf of Mexico. Mar. Geol. 198, 133-158.

Max, M.D., Johnson, A.H., Dillon, W.P., 2006. Economic Geology of Natural Gas Hydrate. Springer, Dordrecht,, 341 pp.

Nehring, R., 1991. Oil and gas resources. In: Salvador, A. (Ed.), The Gulf of Mexico Basin. The Geology of North America, vol. J. GSA, Boulder, CO, pp. 445-494.

Nimblett, J., Ruppel, C., 2003. Permeability evolution during the formation of gas hydrates in marine sediments. J. Geophys. Res. 108, 2420. 2410.1029/ 2001JB001650.
Peel, F.J., Travis, C.J., Hossack, J.R., 1995. Genetic structural provinces and salt tectonics of the Cenozoic offshore U.S. Gulf of Mexico; a preliminary analysis. In: Jackson, M.P.A., Roberts, D.G., Snelson, S. (Eds.), Salt Tectonics. AAPG Memoir 65, 153-175.

Pflaum, R.C., Brooks, J.M., Cox, H.B., Kennicutt, M.C.S.D.D., 1986. Molecular and Isotopic Analysis of Core Gases and Gas Hydrates. DSDP Leg 96. Initial Reports DSDP 96. US Govt. Print. Off., Washington, D.C., pp. 781-784.

Pindell, J., Dewey, J.F., 1982. Permo-Triassic reconstruction of western Pangea and theevolution of the Gulf of Mexico/Caribbean region. Tectonics 1, 179-211.

Prather, B.E., Booth, J.R., Steffens, G.S., Craig, P.A., 1998. Classification, lithologic calibration, and stratigraphic succession of seismic facies of intraslope basins, deep-water Gulf of Mexico. AAPG Bull. 82, 701-728.

Reidel, M., Collett, T.S., Malone, M.J., Expedition.311.Scientists, 2006. Gas hydrate transect across northern Cascadia margin. EOS, Trans. AGU 87 (33), 325-330. 332.

Roberts, H., 1995. High resolution surficial geology of the Louisiana middle-toupper continental slope. Trans. Gulf Coast Assoc. Geol. Soc. XLV, 503-508.

Roberts, H.H., 2001. Fluid and gas expulsion on the northern Gulf of Mexico continental slope; mud-prone to mineral-prone responses. In: Paull, C.K., Dillon, W. (Eds.), Natural Gas Hydrates: Occurrence, Distribution and Detection. American Geophysical Union Monograph, vol. 124, pp. 145-161. Washington, D.C.

Roberts, H.H., Aharon, P., 1994. Hydrocarbon-derived carbonate buildups of the northern Gulf of Mexico continental slope; a review of submersible investigations. Geo Mar. Lett. 14, 135-148.

Roberts, H.H., Carney, R.S., 1997. Evidence of episodic fluid, gas, and sediment venting on the northern Gulf of Mexico continental slope. Econ. Geol. 92, 863-879.

Roberts, H.H., Weimer, P., Rowan, M.G., 1998. Subsurface controls on seafloor vent/seep-related geology, deepwater Gulf of Mexico: initial results. In: Prouty, J.S., Price, K.H., Henderson, V.W. (Eds.). Trans. Gulf Coast Assoc. Geol. Soc. 48 367-372.

Rowe, M.M., Gettrust, J.F., 1993. Fine structure of methane hydrate-bearing sediments on the Blake Outer Ridge as determined from deep-tow multichannel seismic data. J. Geophys. Res. 98, 463-473.

Sager, W.W., MacDonald, I.R., Hou, R., 2003. Geophysical signatures of mud mounds at hydrocarbon seeps on the Louisiana continental slope, northern Gulf of Mexico. Mar. Geol. 198, 97-132.

Sager, W.W., MacDonald, I.R., Hou, R., Sager, W.W., Bryant, W.R., Doyle, E.H., 2004 Side-scan sonar imaging of hydrocarbon seeps on the Louisiana continental slope. AAPG Bull. 88, 725-746.

Salvador, A., 1987. Late Triassic-Jurassic paleogeography and origin of Gulf of Mexico Basin. AAPG Bull. 71, 419-451.

Salvador, A., 1991. Origin and development of the Gulf of Mexico basin. In: Salvador, A. (Ed.), The Gulf of Mexico Basin. The Geology of North America, vol J. GSA, Boulder, CO, pp. 389-444.

Sassen, R., MacDonald, I.R., 1997. Hydrocarbons of experimental and natural gas hydrates, Gulf of Mexico continental slope. Org. Geochem. 26, 289-293.

Sassen, R., MacDonald, I.R., Guinasso Jr., N.L., Joye, S., Requejo, A.G., Sweet, S.T. Alcala-Herrera, J., DeFreitas, D.A., Schink, D.R., 1998. Bacterial methane oxidation in sea-floor gas hydrate: significance to life in extreme environments. Geology 26, 851-854.

Sassen, R., Sweet, S.T., Milkov, A.V., DeFreitas, D.A., Kennicutt II, M.C., Roberts, H.H., 2001. Stability of thermogenic gas hydrate in the Gulf of Mexico; constraints on models of climate change. In: Paull, C.K., Dillon, W. (Eds.), Natural Gas Hydrates: Occurrence, Distribution and Detection. American Geophysical Union Monograph, vol. 124, pp. 131-143. Washington, D.C.

Sassen, R., Roberts, H.H., Carney, R., Milkov, A.V., DeFreitas, D.A., Lanoil, B., Zhang, C. L., 2004. Free hydrocarbon gas, gas hydrate, and authigenic minerals in chemosynthetic communities of the northern Gulf of Mexico continental slope: relation to microbial processes. Chem. Geol. 205, 195-217.

Snyder, F.F.C., Muller, L.K., Dutta, N., Hutchinson, D.R., Hart, P.E., Lee, M.W., Dugan, B., Ruppel, C., Wood, W.T., Coffin, R., Evans, R., Jones, E.H., 2004. Seismic analysis and characterization of gas hydrates in the northern deepwater Gulf of Mexico. AAPG Bull. 88 (No. 13, Suppl.) Available from: http://www.searchanddiscovery. com/documents/abstracts/annual2004/Dallas/Snyder.htm.

Suter, J.R., Berryhill Jr., H.L., 1985. Late quaternary shelf-margin deltas, Northwest Gulf of Mexico. AAPG Bull. 69, 77-91.

Trehu, A.H., Long, P.E., Torres, M.E., Bohrmann, G., Rack, F.R., Collett, T.S., Goldberg, D.S., Milkov, A.V., Riedel, M., Schultheiss, P., Bangs, N.L., Barr, S.R., Borowski, W.S., Claypool, G.E., Delwiche, M.E., Dickens, G.R., Gracia, E., Guerin, G., Holland, M., Johnson, J.E., Lee, Y.J., Liu, C.S., Su, X., Teichert, B., Tomaru, H., Vanneste, M., Watanabe, M., Weinberger, J.L., 2004. Threedimensional distribution of gas hydrate beneath southern hydrate ridge: constraints from ODP Leg 204. Earth Planet. Sci. Lett. 222, 845-862.

Whelan, J.K., Eglington, L., Cathles, L.I., Losh, S.L., Roberts, H., 2005. Surface and subsurface manifestations of gas movement through a N-S transect of the Gulf of Mexico. Mar. Petrol. Geol. 22, 479-497.

Winker, C.D., Booth, J., 2000. Sedimentary dynamics of the salt-dominated continental slope, Gulf of Mexico: integration of observations from the seafloor, near-surface and deep subsurface. In: Proceedings of the GCSSEPM Foundation 20th Annual Research Conference, Deep-water Reservoirs of the World, pp. 1059-1086.

Xu, H., Dai, J., Snyder, F., Dutta, N., 2004. Seismic detection and quantification of gas hydrates using rock physics and inversion. In: Taylor, C.E., Kwan, J.T. (Eds.), Advances in the Study of Gas Hydrates. Kluwer, New York, pp. 117-139.

$\mathrm{Xu}, \mathrm{W}$., Ruppel, C., 1999. Predicting the occurrence, distribution, and evolution of methane gas hydrate in porous marine sediments. J. Geophys. Res. 104, 5081-5096. 